NBER WORKING PAPER SERIES

\title{
STRUCTURAL REFORMS AND ELECTIONS: EVIDENCE FROM A WORLD-WIDE NEW DATASET
}

\author{
Alberto F. Alesina \\ Davide Furceri \\ Jonathan D. Ostry \\ Chris Papageorgiou \\ Dennis P. Quinn \\ Working Paper 26720 \\ http://www.nber.org/papers/w26720 \\ NATIONAL BUREAU OF ECONOMIC RESEARCH \\ 1050 Massachusetts Avenue \\ Cambridge, MA 02138 \\ January 2020
}

We thank participants and discussants in various conference and universities for their valuable comments and suggestions. We are grateful to Hites Ahir, Gabriele Ciminelli, Jun Ge, and Du Huancheng for superb research assistance, and Karina Chavez for excellent editorial assistance. We also thank Haillie Lee, Amy Pond, Maria Toyoda, and Ke Wang for their superb work on the project. This paper is part of a research project on macroeconomic policy in low-income countries supported by the U.K.'s Department for International Development. Quinn gratefully acknowledges support from the National Science Foundation. The views expressed herein are those of the authors and do not necessarily reflect the views of the National Bureau of Economic Research.

At least one co-author has disclosed a financial relationship of potential relevance for this research. Further information is available online at http://www.nber.org/papers/w26720.ack

NBER working papers are circulated for discussion and comment purposes. They have not been peer-reviewed or been subject to the review by the NBER Board of Directors that accompanies official NBER publications.

(C) 2020 by Alberto F. Alesina, Davide Furceri, Jonathan D. Ostry, Chris Papageorgiou, and Dennis P. Quinn. All rights reserved. Short sections of text, not to exceed two paragraphs, may be quoted without explicit permission provided that full credit, including $(\odot)$ notice, is given to the source. 
Structural Reforms and Elections: Evidence from a World-Wide New Dataset

Alberto F. Alesina, Davide Furceri, Jonathan D. Ostry, Chris Papageorgiou, and Dennis P.

Quinn

NBER Working Paper No. 26720

January 2020

JEL No. D72,J65,L43,L51,O43,O47,P16

\begin{abstract}
We assemble two unique databases. One is on reforms in domestic finance, external finance, trade, product markets and labor markets, which covers 90 advanced and developing economies from 1973 to 2014. The other is on electoral results and timing of elections. In the 66 democracies considered in the paper, we show that liberalizing reforms engender benefits for the economy, but they materialize only gradually over time. Partly because of this delayed effect, and possibly because voters are impatient or do not anticipate future benefits, liberalizing reforms are costly to incumbents when implemented close to elections. We also find that the electoral effects depend on the state of the economy at the time of reform: reforms are penalized during contractions; liberalizing reforms undertaken in expansions are often rewarded. Voters seem to attribute current economic conditions to the reforms without fully internalizing the delay that it takes for reforms to bear fruit.
\end{abstract}

\author{
Alberto F. Alesina \\ Department of Economics \\ Harvard University \\ Littauer Center 210 \\ Cambridge, MA 02138 \\ and IGIER \\ and also NBER \\ aalesina@harvard.edu \\ Davide Furceri \\ International Monetary Fund \\ 700 19th Street N.W. \\ Washington, DC 20431 \\ dfurceri@imf.org \\ Jonathan D. Ostry \\ Research Department \\ International Monetary Fund \\ HQ1-10-700 \\ 700 19th Street, N.W. \\ Washington DC, 20431 \\ and CEPR \\ jostry@imf.org
}

\author{
Chris Papageorgiou \\ International Monetary Fund \\ 700 19th St. N.W. \\ Washington, DC 20431 \\ cpapageorgiou@imf.org \\ Dennis P. Quinn \\ McDonough School of Business \\ Georgetown University \\ Washington, DC 20057 \\ quinnd@georgetown.edu
}


"It ought to be remembered that there is nothing more difficult to take in hand, more perilous to conduct, or more uncertain in its success, than to take the lead in the introduction of a new order of things. Because the innovator has for enemies all those who have done well under the old conditions, and lukewarm defenders in those who may do well under the new."

Niccolò Machiavelli, 1505.

\section{INTRODUCTION}

This paper has three goals. First is to introduce two new datasets. Our "Structural Reform Database (SRD)" assembles and describes what is, as far as we know, the most comprehensive data set on economic reforms for 90 countries for the period 1973 to 2014. These reforms include both domestic ones, such as goods and labor market reforms, and international ones such as trade and external financial liberalization. The reforms we document measure either a liberalization or a tightening of regulation. For brevity we label "reform" a move toward liberalization; we make it clear where relevant to distinguish between liberalizations and reversals or 'tightening'. We construct an index which summarizes all the reforms - the arithmetical average of all reform indicators-but we also explore separately specific types of reform. Our second dataset includes the precise timing and detailed electoral results in 66 democracies over the period from 1960 to 2018. The dataset also includes detailed institutional information on the electoral systems used. Our second goal is to analyze the consequences for economic growth of these reforms, which may vary depending upon when during the business cycle they are implemented. The third goal is to examine the electoral consequences of reform using our dataset on electoral outcomes for 66 democratic countries.

We begin by documenting the evolution of reforms around the world. Since the late 1980s, there has been a broad tendency toward liberalization across advanced and developing economies, but the pace has declined since the Global Financial Crisis. This has been especially notable for reforms covering domestic finance (mainly banking reforms), and the external current and capital accounts, where there has been a (modest) reversal of reform in some countries. The pattern of reform has been heterogeneous across regions. Liberalizing reforms have been more aggressive in Europe, much less so in the Middle East, Central Asia and Sub-Saharan Africa. By 2014, the level of regulation 
in these latter regions remains significantly tighter than in Europe. We describe the dataset and the reform patterns below and in more detail in the online appendix, Appendix 1 “The Structural Reform Dataset.”

Our second set of results concerns the economic effects of reforms. We show that liberalizing reforms are followed by an increase in growth, but with a lag of almost four years. Regulatory tightening has immediate negative consequences for growth, but these tend to dissipate over the medium term. The positive effects of liberalization and the negative effects of tightening are similar in size. We also show that reforms implemented in good times (i.e., in business cycle booms) generate additional growth compared to reforms implemented in bad times (i.e., in recessions).

The third set of results is on the electoral effects of reforms. We show that timing is crucial along two dimensions: when the reform occurs relative to the electoral cycle and when it occurs relative to the business cycle. Voters do not seem to fully internalize the time that it takes for a reform to generate its effects on the economy. A liberalization taken in the year ahead of an election is punished by the voters, who may not see any immediate economic benefit on average, with certain sectors even experiencing economic losses. The vote share of the main governing party (or coalition) declines following reforms implemented in an election year, while the political cost disappears when reforms are implemented earlier in the electoral cycle. The state of the business cycle also shapes electoral consequences. We show that when economies are in contraction, liberalizations (and tightening) are penalized at the ballot box. In contrast, reforms undertaken during an expansion are not punished, and in some cases, are even rewarded. Voters seem to have a hard time distinguishing between the effects of the business cycle (with its manifold causes) and the reform itself, penalizing a government electorally for reforms implemented during weak economic conditions. This result is quite reasonable given the non-trivial delay in the realization of the positive effects of reforms, which we have documented.

Obviously, the choice of whether and when to implement reforms is endogenous. Nevertheless, we find that most reforms are implemented during recessions, which seems counterproductive from an electoral point of view. This suggests that often reforms are imposed by the events during recessions or crises, thus when the timing may not be 
optimal from a political standpoint. In any event, one must consider the endogeneity of the reform effort. For instance, a government may choose to adopt reforms when it knows it can be reelected despite the reform due to its popularity across other dimensions. This endogeneity may make the negative electoral effects of reforms look smaller (in absolute terms). Another possible concern with endogeneity is that in some countries the government has (some) discretion on when to call elections, while in others the discretion does not exist.

We try to address endogeneity in three ways. First, we consider reforms imposed from abroad: those mandated because of an IMF-supported program. Second, we use an instrumental variable (IV) approach, with the instrument based upon improvements in democracy in trading partners (Giuliano et al., 2013; Acemoglu et al., 2019). Third, we investigate the sub-sample of countries in which the timing of elections is exogenousthat is, those countries in which the government has no discretion in calling new elections. In each of these three approaches, the results point to stronger negative effects of reforms on vote shares for the incumbent engaged in reform. This is consistent with the OLS-baseline coefficient estimates being biased downward.

Finally, we investigate whether our results differ across different types of political systems, and country income groups: majoritarian versus proportional; coalitions versus single-party government; new versus established democracies; and advanced versus developing economies. We find that single party governments are punished more than the party leader of a coalition government for election-year reforms, which seems consistent with an attribution of responsibility, full for a single party government, shared in a coalition government. Financial sector liberalizations are particularly costly to incumbents. Electoral effects do not seem to vary significantly between majoritarian and proportional systems or between new versus established democracies. The negative effects of election-year reforms are larger in developing countries, although the differences with developed economies are not statistically significant at standard statistical levels.

The remainder of the paper is organized as follows. Section II provides a brief review of the literature on the economic and political effects of structural reforms. Section III describes in some detail the structural reform indicators and introduces the 
electoral outcome dataset. Section IV describes the evolution of the reform process in the last decades. Section V presents estimates of the growth effects of reforms. Section VI examines the electoral impact of reforms. Section VII discusses endogeneity issues with respect to the timing of reforms. Section VIII presents various extensions and the last section concludes.

\section{REVIEW OF THE LITERATURE}

This section presents a selected survey of the literature on the economic and political effects of reforms. For more extensive surveys, we refer to Ostry et al. (2009), Henry (2007), Abiad and Mody (2005), Bekaert et al. (2005), Sturtzenegger and Tommasi (1998), Haggard and Webb (1994), and Giuliano et al. (2013).

\section{A. The economic effects of reforms}

Prati, Onorato, and Papageorgiou (2013) find that, on average, both trade and financial sector reforms boost growth. Tressel and Detragiache (2008) show that domestic financial reforms are associated with growth in countries with good institutions, and Quinn and Toyoda (2008) show that capital account liberalization is positively associated with medium-term growth. Finally, recent empirical work provides evidence that structural reforms improve economic performance in advanced economies. Duval and Furceri (2018) show that reforms in product and labor markets in 26 OECD countries raise growth, although with significant lags.

The timing of reform's growth benefits is unlikely to be immediate, however. Blanchard and Giavazzi (2003) model labor and product market deregulations in the context

of frictions, and find that short-term decreases in wages and employment, especially for those employed in "incumbent industries," are likely from liberalizations. Bassinini and Cingano (2018), using the OECD labor markets database, find "transitory" increases in unemployment, especially in recessionary periods, from liberalizations. 


\section{B. Electoral effects}

Economic conditions. Starting with Kramer (1977), Fair (1978), and Tufte (1978), for the US, many studies show that voters are more likely to support incumbents and their parties during good economic times, and to vote for the opposition when economic conditions deteriorate (see Lewis-Beck and Tien (2008) for a review of this literature). Quinn and Woolley (2001) show that increasing economic volatility reduces the vote shares of incumbent candidates and parties in a comparative, cross-national setting. Increased international economic exposure, which follows from reforms in trade and capital account, also appears to affect incumbent electoral outcomes. Margalit (2011), Feigenbaum and Hall (2015), Autor et al. (2016), and Che et al. (2016) find that trade exposure in import-competing industries has electoral effects: politicians who advocate free trade receive fewer votes in constituencies with high manufacturing trade exposure, especially to Chinese imports. Jensen, Quinn, and Weymouth (2017) show a strong electoral effect from both the winners and losers of trade exposure: high-skilled tradable service industry employment and low-skilled tradable manufacturing employment is associated with increasing and decreasing incumbent vote shares, respectively.

Political Budget Cycles. A related literature studies whether policy actions taken to eliminate structural deficits (and reduce inflation) are electorally costly. The literature on this point is vast but a few recent pieces of work summarize the findings well. In an influential study, Brender and Drazen (2008) find that voters are likely to punish rather than reward persistent budget deficit over the leader's term in office, especially in developed economies. Alesina et al. (2019a) show that, on average, governments that

drastically reduce budget deficits are not systematically punished at the polls. Alesina et al. (2019b) find evidence that tax-based fiscal adjustments are punished by voters, but expenditure-based ones are not.

The Direct Electoral Costs of Reforms. While there has been theoretical work rationalizing the electoral outcomes of enacting reforms, empirical evidence is typically scant, based on a limited set of countries and with mixed results. Pacek (1994) finds that almost all post-communist reform governments were penalized at the polls. Weyland (1998) finds mixed electoral fates for reforming governments in Latin America. Buti et al. (2010) examine the effects of a de facto measure of structural reforms-indices of 
types of "market rigidities" for 21 OECD countries - and they report that changes in the overall market rigidity indicator have no electoral effect on incumbents.

Imposed or chosen reforms. Dreher (2004) tests whether IMF program participation affects incumbents' re-election prospects and shows that governments tended to avoid Fund program participation in advance of elections. When crises are severe, entering a Fund program increases the likelihood of reelection; in better economic times, entering a Fund program decreased the likelihood of reelection. These results, however, only hold in less democratic countries (those with a POLITY score less than seven).

\section{DATA}

\section{A. Policy Reforms}

We build the most comprehensive dataset to date of structural reform regulation for a large sample of 90 developing and developed countries. This dataset is unique in terms of country-time coverage and in the breadth of the areas covered. The indicators of regulation constructed cover both financial and real sector reforms. The former includes domestic finance, as well as financial current account and capital account reforms. Real sector reforms are divided into trade (tariff), product and labor market reforms. All indicators are scaled to vary between zero and one, with higher values representing greater liberalization. Differences in the values of each indicator across countries and over time indicate the variation in the absolute degree of economic reform within each sector. The dataset also identifies, documents, and provides the implementation date of major reforms and reversals in the policy areas covered in this paper.

We do not treat reform as a 0-1 variable. Both logic and description of actual episodes of reforms suggest that reforms are best described as lying on a continuum rather than as dichotomic events of similar intensity. Treating a continuous variable as discrete introduces measurement error because a small error in accuracy in evaluating an observation can cause a large change in the value assigned to it.

The dataset was compiled through a systematic reading and coding of policy actions documented in various sources, including national laws and regulations, as well 
as IMF staff reports. ${ }^{1}$ To address potential concerns regarding accuracy, reliability and consistency of our dataset, we evaluate the indicators in several ways. First, we compare our indicators to those existing in the literature, typically available for a smaller set of economies and time periods. ${ }^{2}$ Second, we show that our indicators are consistent with the relevant de facto measures (such as financial depth, trade and financial openness). Third, we cross-check that major changes in the reform indicators are associated with major reform events identified in previous work. ${ }^{3}$ Our database covers a balanced sample of 90 countries over the period 1973-2014 (Table 1). ${ }^{4}$ It includes 29 advanced economies, 50 emerging markets, and 21 low-income countries, with a broad geographical representation. The countries included represent 96 percent of the world's 2017 GDP.

Domestic financial sector. We construct the structural reform indicator for domestic finance following the approach used in Abiad, Detragiache, and Tressel (2009). We consider six dimensions of domestic finance regulation: credit controls; interest rate controls; bank entry barriers; banking supervision; privatization; and security market development. Along each dimension except banking supervision, a country is scored from 0 (highest degree of repression) to 1 (full liberalization). For the banking supervision dimension, tighter regulations - whether a country has adopted a capital adequacy ratio based on the Basel standards, and whether it has an independent banking supervisory agency—are associated with a higher score.

Current and capital account. These indicators follow the approach used in Quinn (1997) and Quinn and Toyoda (2008). ${ }^{5}$ We also construct sub-indicators of the capital

\footnotetext{
${ }^{1}$ The data sources are described in greater detail in the online Appendix 1. Five of the six reform areas (trade tariffs excepted) are based on coding of the laws and policies governments used to regulate economic activity in the relevant area. Teams of experts in each reform area were assembled, and coding rules were developed. For text-based coding, multiple coders independently scored rules and regulations in terms of the intensity of regulatory restrictions, with other coders reconciling differences.

${ }^{2}$ Other scholars and institutions have developed structural reform indicators over the past two decades in the areas of: (i) domestic finance (e.g., Abiad et al., 2009); (ii) openness to external finance (e.g., Chinn and Ito, 2008; Quinn and Toyoda, 2008; Fernández et al., 2016); (iii) financial current account openness and trade (Quinn and Toyoda, 2008; the World Bank); product market regulation (OECD); and labor market regulation (Botero et al., 2004; Campos and Nugent, 2012).

${ }^{3}$ For product and labor market regulations in advanced economies for instance, Duval et al., 2017.

${ }^{4}$ Post-Soviet countries are available from 1991 or 1992 onward.

${ }^{5}$ The data on the capital account extension draw on joint work with Haillie Lee, Amy Pond, and A. Maria Toyoda.
} 
account for inward and outward foreign direct investment, portfolio investment, bond market, money markets, and finance and lending markets. These de jure indicators are based on the laws and regulations described in the IMF’s Annual Report on Exchange Arrangements and Exchange Restrictions (AREAER). They contain information about policy based on six categories: payment for imports, receipts from exports, payment for invisibles, receipts from invisibles, capital flows by residents, and capital flows by nonresidents.

Trade. The indicator measures trade tariffs at the product level. Product-level tariff data are aggregated by calculating simple and weighted averages, with weights given by the import share of each product. These averages are normalized from 0 (closed to trade, corresponding to the highest tariff in the sample, about 110 percent) to 1 (fully open to trade, corresponding to the lowest tariff in the sample, 0 percent).

Product market. The indicator covers liberalization in two network sectors: telecommunication and electricity. For each of these components, four dimensions of regulation are considered. For telecommunications, these are: competition; state ownership; the presence or absence of an independent regulatory agency; and the degree of government intervention in access to telecommunications. For electricity markets, the measures are as follows: the bundling or unbundling of generation; transmission distribution; state ownership; the presence or absence of an independent regulatory agency; and the degree of liberalization in the wholesale market. Along each of the four dimensions, a country is scored from 0 (highest degree of repression) to 1 (full liberalization).

Labor market. The labor market liberalization (LML) indicator provides a new measure of employment protection legislation (EPL) related to the termination of fulltime indefinite contracts for objective reasons. Three dimensions of EPL are considered: (1) procedural requirements, such as third-party approval; (2) firing costs, including severance payments and note requirements; and (3) grounds for dismissal with the possibility (or not) of redress. Each sub index is constructed by taking the simple average of several indicators and is normalized to range from 0 (highest regulation) to 1 (highest liberalization). We consult statutory legislation setting minimum requirements to generate this indicator. To reconstruct the history of EPL in each country, we use the most recent 
laws as a reference point. Next, three distinct approaches are followed to analyze older legislation. First, we check whether the most recent laws specify which older laws they repealed or amended upon their entry into force. Second, we check the coverage of older legislation. Third, we study country-specific databases and other documents, such as government gazettes and parliamentary records. In a final step we cross-check the data from different sources.

\section{B. Electoral data}

The electoral dataset contains information on each election taken place in the countries covered in the structural reform database, from 1960 onward. ${ }^{6}$ The most relevant information contained are: (i) the election date; (ii) the name of the incumbent leader (prime minister or president) and his/her party affiliation; (iii) the name of the new leader and party affiliation; (iv) the date in which the incumbent leader took office; (v) the vote share of the (coalition of) party (parties) supporting the incumbent at the current, last and second-last elections. Additional information includes the types of political systems (presidential vs. parliamentarian), the electoral system (majoritarian vs. proportional) and the number of parties in the coalition. We describe the dataset below and in more detail in the online appendix, Appendix 2 "Electoral Dataset Appendix." 7

In this paper, we use an unbalanced sample of democratic elections from the beginning of our reform data, namely 1973 (or the first year in which the country is characterized as a democratic regime) to 2014 for 66 countries (Table 2). The identification of democratic regimes is based on the POLITY2 score-a measure of regime characteristics ranging from -10 (strongly autocratic) to 10 (strongly democratic) published by Marshall el al. (2017). A country is defined as having a democratic regime if its POLITY2 score is

\footnotetext{
${ }^{6}$ The analysis on the electoral effects of reform is restricted to cover an unbalanced sample of democratic elections from 1973 (or the first year in which the country is characterized as a democratic regime) to 2014 for 66 economies.

${ }^{7}$ Two other excellent electoral datasets are available. These are Dawn Brancati's Global Elections Database and Scartascini et al.'s (2018) Database of Political Institutions 2017. GED covers the elections in 57 countries in detail but stops (depending on the country) in the mid-2000s.
} 
greater than $6 .{ }^{8}$ Overall, the dataset contains information on 495 elections, of which 327 those used in the empirical analysis-are for countries meeting the democracy threshold.

The start and end dates in office, as well as the party affiliation for the head of government in each country, are taken from the Database on World Political Leaders produced by Roberto Ortiz de Zárate (2019). The person acting as head of the government (parliamentary systems) or president (presidential systems) preceding the election is recorded as the incumbent. The party to which the incumbent is affiliated is recorded as the incumbent's party. The parties running on the same ticket of the incumbent's party are recorded as part of the coalition government. We account for changes of party names, mergers and separations. This allows us to accurately calculate the length of the tenure of the leaders as well as that of the parties in office.

In the analysis, the dependent variable is the vote share of the incumbent's party. The main sources are the official records released by each country's electoral authority. To ensure accuracy, we complement and cross-check this information with the vote shares reported in the Global Elections Database (Brancati, 2013) and the Adam Carr’s Election Archive. In addition to the vote share for individual parties, we also compute the vote share of the coalition of governing parties. In cases where there are no separate vote data for each party in a coalition, the incumbent party vote share is recorded as missing, while coalition vote shares data are recorded for the incumbent.

The main explanatory variables used in the analysis are: (i) the reform in the election year, and (ii) the reform in the rest of the term. Reforms in the election year are measured by the change in the structural reform indicator during the year of the election. When elections take place in the first three months of the year, we code reforms as the change in the indicator in the year before. Reforms in the rest of the term are measured by the change in the indicator between the beginning of the incumbent term and the year prior to elections. To make these two variables comparable, we divide the reform in the rest of the term by the number of years in the rest of the term.

\footnotetext{
${ }^{8}$ Democracies are defined, consistent with the recommendations of the creators of the Polity index, as countries with scores greater than six. See Center for Systemic Peace (2016); Marshall et al. (2017).
} 


\section{PATtern OF Reforms}

In this section we present broad patterns of structural reforms across time and country groups. Appendix 1 reports more details including descriptive statistics and other empirical regularities of the data. First, there has been a significant, but heterogeneous, reform effort in the past four decades (Figure 1): since the late 1980s, there has been a broad tendency to pursue liberalization across advanced and developing economies (Panel A). The pace of liberalization, however, has typically declined since the Global Financial Crisis (GFC). This has been especially the case in the areas of domestic finance, and financial current and capital account regulation, where we observe a modest reversal of reforms in some countries. Second, the reform process has proceeded unevenly across different sectors (Panel B): reforms appear to have been more frequent in domestic finance, trade, capital and current account than in product and labor markets. In addition, major liberalization pushes across different areas have occurred in different periods: trade reforms occurred in the 1970s and 1980s; domestic and external finance reforms in the early 1990s; and product market reforms in the late 1990s. In labor market regulation (EPL), we find no deregulation trend, but even a regulatory tightening in recent years. Third, advanced economies tend to be characterized by less stringent regulations than emerging markets and low-income counties (Panel C). In addition, while emerging markets and low-income countries had a similar degree of regulation until the 1990s, reform progress has been stronger in emerging markets than in low-income countries since then. Again, labor market regulation (EPL) is an exception, where no systematic differences emerge across countries at different levels of development. Fourth, reform progress has been heterogeneous across different regions (Panel D): it has been the strongest in Europe, while it has been generally modest in the Middle East and Central Asia and in Sub-Saharan Africa.

Despite this broad tendency toward liberalization, there have been several cases of tightening of regulation and major reform reversals especially regarding employment protection legislation. Tightening reforms have occurred also in other regulatory areas both in advanced and developing economies. Major examples include the capital and current accounts regulatory tightening in Argentina after the collapse of the currency board in the early 2000s; the significant increase in tariffs in Thailand following the crisis 
in the late 1990s; the increase in domestic financial regulation in Ecuador in the mid2000s; the reversal of the privatization of the electricity sector in Jordan in 2011; and the tightening labor market reforms in Portugal in the mid-1970s.

\section{A. Reforms in the electoral cycle}

Table 3 shows the intensity of reforms - that is, the annual change in the reform indicator-during the incumbent leader's electoral term. Two key general patterns are noticeable. First, the extent of liberalization reforms is lower during the year of the election than in the rest of the leader's electoral term. This may suggest that governments could have stronger political support to implement reforms at the beginning of their mandate; and/or; elected politicians may opt out from implementing reforms immediately before an election because of the fear of jeopardizing their re-election. Interestingly, the opposite holds for tightening reforms, the intensity of which is relatively large during an election year, possibly as a result of the government's attempt to gain support from special interest groups.

Second, liberalization reforms (both in election years and in the rest of the government's term) are more frequent and are larger in magnitude when economic conditions are weak. This suggests that often they are imposed in a situation of crisis when the timing does not seem optimal. In contrast, tightening reforms (both in election years and in the rest of the government's term) are more frequent when the economy is in an economic expansion.

\section{THE EFFECTS OF REFORMS ON THE ECONOMY}

We use two econometric specifications to estimate the macroeconomic impact of reforms. The first establishes whether reforms have significant effects on output. The second assesses whether these effects vary with the state of the economy prevailing at the time of the reform.

We follow the approach proposed by Jordà (2005) to estimate impulse-response functions, a methodology used also by Auerbach and Gorodnichencko (2013), Ramey and Zubairy (2018), and Alesina et al. (2019b) among others. This procedure does not impose the dynamic restrictions embedded in vector autoregression specifications and is 
particularly suited to estimating nonlinearities in the dynamic response. The first regression we estimate is:

$y_{t+k, i}-y_{t-1, i}=\alpha_{i}+\gamma_{t}+\beta_{k} \Delta R_{i, t}+\theta X_{i, t}+\varepsilon_{i, t}$

in which $y$ is the log of output; $\alpha_{i}$ are country fixed effects, included to take account of differences in countries' average growth rates; $\gamma_{t}$ are time fixed effects, included to take account of global shocks such as shifts in oil prices or the global business cycle; $\Delta R$ denotes the change in the reform indicator. Note that $R$, the reform index, is increasing with the degree of liberalization, thus a liberalizing reform implies a positive value of $\Delta R_{i, t}$ and a tightening is a negative value. $X$ is a set of control variables including two lags of the dependent variable, two lags of the change in the reform indicator, and country-specific time trends - to account for country-specific regulation patterns before the reform.

The second specification allows the response to vary with business cycle conditions (a continuum of states between extreme recessions and booms) at the time of the reform. It is estimated as follows:

$y_{i, t+k}-y_{i, t-1}=\alpha_{i}+\gamma_{t}+\beta_{k}^{L} F\left(z_{i, t}\right) \Delta R_{i, t}+\beta_{k}^{H}\left(1-F\left(z_{i, t}\right)\right) \Delta R_{i, t}+\theta Z_{i, t}+\varepsilon_{i, t}$

with $F\left(z_{i t}\right)=\exp ^{-\gamma z_{i t}} /\left(\exp ^{-\gamma z_{i t}}\right), \quad \gamma>0$

where $\mathrm{z}$ is an indicator of the state of the economy normalized to have zero mean and a unit variance. The indicator of the state of the economy considered in the analysis is GDP growth. ${ }^{9}$ The weights assigned to each regime vary between 0 and 1 according to the weighting function $F($.$) , so that F\left(z_{i t}\right)$ can be interpreted as the probability of being in a given state of the economy. The coefficients $\beta_{L}^{k}$ and $\beta_{H}^{k}$ capture the impact of reforms at each horizon $k$ in cases of extreme recessions $\left(F\left(z_{i t}\right) \approx 1\right.$ when $z$ goes to minus infinity) and booms (1 $F\left(z_{i t}\right) \approx 1$ when $z$ goes to plus infinity), respectively. ${ }^{10}$ We choose $\gamma=1.5$, following

\footnotetext{
${ }^{9}$ We use contemporaneous GDP growth as reforms do not have a significant contemporaneous effect on GDP. Similar results are obtained when using lagged GDP growth.

${ }^{10} F\left(z_{i t}\right)=0.5$ is the cutoff between weak and strong economic activity.
} 
Auerbach and Gorodnichenko (2012), so that the economy spends about 20 percent of the time in a recessionary regime-defined as $F\left(z_{i t}\right)>0.8$-close to the typical business cycle pattern of advanced and emerging market economies. ${ }^{11} Z_{i t}$ is the same set of control variables used in equation (1) but now also including $\mathrm{F}\left(\mathrm{z}_{i t}\right)$ to control for the state of the business cycle at the time of the reforms.

This approach is equivalent to the smooth transition autoregressive model developed by Granger and Terävistra (1993). The advantage of this approach is twofold. First, compared with a model in which each dependent variable would be interacted with a measure of the business cycle position, it permits a direct test of whether the effect of reforms varies across different regimes such as recessions and expansions. Second, compared with estimating structural vector autoregressions for each regime, it allows the effect of reforms to change smoothly between recessions and expansions by considering a continuum of states to compute the impulse response functions, thus making the response more stable and precise.

Equations ( 1 and 2 ) are estimated for each $\mathrm{k}=0, . ., 5$. Impulse response functions are computed using the estimated coefficients $\beta_{k}$, and the confidence bands associated with the estimated impulse-response functions are obtained using the estimated standard errors of the coefficients $\beta_{k}$, based on clustered robust standard errors. Figure 2 shows the estimated dynamic response of GDP to a major historical reform-identified as a change in the aggregate reform indicator above two standard deviations of the average change in the indicator-over the five-year period following reform implementation, together with the 90 percent confidence interval around the point estimate. Major deregulation episodes have a positive and statistically-significant (at 5 percent) output effect of about 1 percent five years after the reform.

The dynamic effect of the reform varies between liberalizing reforms and tightening reforms (Figure 3). ${ }^{12}$ The former increases output in the medium term-with the effect being statistically significant only four years after the reform, while tightening reforms leads to a contraction in output in the short term-with the effect becoming less

\footnotetext{
${ }^{11}$ Our results hardly change when using alternative values of the parameter $\gamma$, between 1 and 6 .

12 The number of liberalizing and tightening reforms are 1772 and 620, respectively.
} 
precisely estimated in the medium term. The difference in the absolute value of the effect between liberalizing and tightening reforms is not statistically significant.

The response of growth to reforms (both liberalizing and tightening) masks different effects according to overall business conditions (Figure 4). Liberalizing (tightening) reforms tend to deliver larger payoffs (more limited output losses) when carried out in expansions than in recessions. This result is consistent with previous empirical studies showing asymmetric effects across different economic regimes for specific reforms such as changes in tariff rates (Furceri et al., 2018) and labor market reforms (Duval and Furceri, 2018). ${ }^{13}$

We draw attention to two core results. First, liberalizing reforms take a while, up to four years, to show their positive effects on growth; tightening reforms, in contrast, have a negative, more-immediate, impact on the economy. Second, reforms tend to generate higher growth if implemented during an upturn of the business cycle. These points are relevant for the electoral effects of reforms to which we now turn.

\section{ELECTORAL IMPACT OF ECONOMIC REFORMS}

\section{A. Reforms and elections}

We begin by estimating the effects of reforms on the change of vote shares of the incumbent party (or the coalition of parties), for both reforms introduced in the election year and reforms introduced during the rest of the government's term as described above. The coefficients we are mostly interested in are those on various measures of reforms, but of course we control for other determinants of electoral outcomes.

\footnotetext{
${ }^{13}$ One of the reasons the impact of tariffs depends on the state of the business cycle is related to the effect of tariffs on inflation and the role of monetary policies. An increase in tariffs acts as a supply shock by decreasing output and increasing inflation in the short run. This, in turn, prompts central banks to respond with a contractionary impulse, thereby magnifying the negative effect of tariffs (Barattieri et al., 2018). For labor market reform, the theoretical rationale is that reform affects differently firms' hiring versus firing incentives in good and bad times. In a recession, firms seek to dismiss more and hire less than in a boom, but stringent job protection discourages them from laying off; relaxing that constraint triggers more layoffs, increasing unemployment, weakening aggregate demand and delaying recovery (Cacciatore et al., 2016b).
} 
In the benchmark specification, we control for average GDP growth during the electoral term and three binary indicators (see Table 2): a developed-country dummy ( 1 = countries defined as advanced economy according to the IMF classification and 0 otherwise); a dummy variable for new democracies ( 1 = countries for the first four elections after a year with a negative Polity score on the -10 to 10 scale, and 0 otherwise); and a dummy variable for a majoritarian political system $(1=$ countries with an electoral system that awards seats in "winner-take-all” geographically-based districts according to the Database of Political Institutions, and 0 otherwise: Cruz, Keefer, and Scartascini, 2016). In line with Brender and Drazen (2008), we estimate the following specification:

$\Delta$ Incumbent Party Vote Share $_{i, t}=\beta_{0}+\beta_{1}$ Reform $_{\text {ey }}$ f $_{i, t}+\beta_{2}$ Reform $_{\text {term }_{i, t-1}}+$ $\beta_{3}$ Growth $_{\text {ey }_{i, t-1}}+\beta_{4}$ Growth $_{\text {term }_{i, t-1}}+\beta_{4}$ Developed Country $_{i}+$ $\beta_{5}$ Developed Country $_{i, t}+\beta_{6}$ Majoritarian system $_{i, t}+\beta_{7}$ Initial Regulation $_{i, t-x}+$ $\beta_{8}$ Incumbent Party Vote Share $_{i, t-1}+\varepsilon_{i, t}$,

where $i=$ (country), $t=($ election year). We explicitly examine changes in the reform index in the year of election: Reform_eyi,t, which is the change in the unweighted average of all reform indicators in the year of an election. When elections take place in the first three months of the year, we code reforms as the change in the indicator in the year before. ${ }^{14}$ We also examine Reform_term_rest $i, t-x$, which is the change in the aggregate reform index in the rest of the incumbent's term, plus the initial level of the indicator at the start of the incumbent's term, given that the reform indicators are bounded between zero and one. Equation 3 is estimated using a panel pooled OLS estimator.

A positive value of the reform indicator captures a move toward liberalization, while a negative sign a move away from it. Thus, a positive sign on the coefficient on that variable implies an increase in the dependent variable when the reforms move toward liberalization. All the results are scaled to denote the electoral effect of a major reform-

\footnotetext{
${ }^{14}$ Brender and Drazen (2008) exclude situations where incumbents have been in power less than two years, which in practice means a government may have been in power for up to 35 months and still not appear in their data. Countries with frequent parliamentary elections prior to the end of a full-term are under-represented in their data.
} 
identified as a change in the aggregate reform indicator above two standard deviations of the average change in the indicator.

We begin by presenting the results in Table 4 with reforms during the election year and find that they are associated with a statistically-significant decrease in the vote share. We find that a major reform is associated with a 2.7 percentage point decrease in vote share (column I) — which is approximately a $\frac{1}{2} 2$ standard deviation of the change in vote share in our sample.

Better economic conditions during either the election year or the incumbent's term are associated with more favorable political outcomes. In addition, we find that the changes in vote shares are typically larger in advanced economies and in the majoritarian system. The results are robust to including country fixed effects (column II), countryspecific time trends (column III), and extending the set of controls to include changes in the budget balance and inflation during the electoral term (column IV). The magnitude of the effect of reforms on the vote share is almost identical, albeit larger, to the one obtained in the baseline, although less precisely estimated.

In Table 5, we repeat the exercise for reforms implemented during the rest of the government's term - measured by the change in the indicator between the beginning of the term and the year prior to an election. There is no negative effect on vote share for the incumbent in this case. The other coefficients remain stable relative to those in Table 4. When we introduce both reforms in the election year and in the rest of the term (Table 6), the election-year regressor maintains the same negative and statistically-significant effect as in Table 4 and the ““'rest-of-the-term” regressor remains insignificant as in Table 5.

\section{B. Economic conditions at the time of reform}

We use the smooth transition function described in equation (2) to allow the electoral effect of reforms to vary with the overall business cycle conditions at the time of the reform. Specifically, we estimate the following equation:

$\Delta$ Incumbent Party Vote Share $_{i, t}=\beta_{0}+F\left(z_{i, t}\right)\left[\beta_{1}^{L}\right.$ Reform $_{\text {ey }_{i, t-1}}+$

$\left.\beta_{2}^{L} \operatorname{Reform}_{\text {term }_{i, t-1}}\right]+\left(1-F\left(z_{i, t}\right)\right)\left[\beta_{1}^{H} \operatorname{Reform}_{e y_{i, t-1}}+\beta_{2}^{H}(1-\right.$ 
D) Reform term $\left._{i, t-1}\right]+\beta_{3}$ Growth $_{\text {ey }_{i, t-1}}+\beta_{4}$ Growth $_{\text {term }_{i, t-1}}+$ $\beta_{4}$ Developed Country $_{i}+\beta_{5}$ NewDemocracy $_{i, t}+\beta_{6}$ Majoritarian system $_{i, t}+$ $\beta_{7}$ Initial Regulation $_{i, t-x}+\beta_{8}$ Incumbent Party Vote Share $_{i, t-1}+\varepsilon_{i, t}$ where $i=$ (country), $t=($ election year).

As before, the coefficients $\beta_{1,2}^{L}$ and $\beta_{1,2}^{H}$ capture the electoral impact of a major reform in cases of extreme recessions $\left(F\left(z_{i t}\right) \approx 1\right.$ when $z$ goes to minus infinity) and booms ( 1 $F\left(z_{i t}\right) \approx 1$ when $\mathrm{z}$ goes to plus infinity), respectively.

The results suggest a marked difference between the effects of reforms in good and bad times. The negative effect of reforms is concentrated solely among those enacted in election years with weak economic activity (Table 7). In bad times, a major reformidentified as a change in the aggregate reform indicator above two standard deviations of the average change in the indicator-is associated with a decline in the vote share of about 4 percentage points. Note that, and this is important, we are still controlling for growth in the election year and in the rest of the electoral term.

In Table 8, we investigate whether liberalizing and tightening reforms produce differing electoral effects by allowing for different coefficients in the estimation for the indicator of reforms, depending on whether the reforms are liberalizing (positve) or tightening (negative). Note that, when the reform indicator has a negative value (tightening reforms), a positive coefficient implies that the reform leads to a loss of votes, and vice-versa. For ease of interpretation, we report the value of the coefficients for tightening reforms with the sign switched: the reported coefficients for tightening or reversals indicate the loss of votes for a given (negative) change in the reform index.

The results in column (I) suggest that while liberalizing reforms have a negative and statistically-significant electoral cost when implemented during the election year, tightening reforms tend to increase the vote share of the incumbent coalition. The estimated 'tightening' coefficient is, however, far from being statistically significant.

When we allow the effect of reforms and reversals to vary between good and bad economic times (column II as given in equation (4)), we continue to find that election year reforms during recessions harm incumbent vote shares. A striking result in column (II) is that incumbents are punished for reforms and reversals during the rest of their term when either 
occurs in recession years. Incumbents, in contrast, are rewarded for reforms and reversals in non-election years when either occurs in expansions_-remember that we are still controlling for the rate of growth of the economy.

It is important to note that while the effects reported are quite large, they also portray hypothetical situations that have never occurred, such as a major tightening reform of two standard deviations in the change of the indicator in periods of major recession or expansion. ${ }^{15}$ In particular, they suggest that in the extreme (and hypothetical) case of a protracted and extreme recession (expansion) — that is, lasting for the entire electoral term major changes in the reform indicator for the entire electoral term would lead to a decline (increase) in the vote share of about 21 (31) percentage points. The effects are considerably smaller when considering the average changes (both positive and negative) in the reform indicator during average recessions and expansions (that is, $F\left(z_{i, t}\right)=00.75$ ). In these circumstances, the effect on the vote share of the government party during recessions and expansions is -2.2 and 4.7 percentage points, respectively.

These results suggest that voters associate poor economic conditions with reforms, liberalization or tightening in regulation, undertaken by the government. The opposite occurs for reforms implemented during expansions. In other words, any policy which occurs during a recession is viewed as "responsible" for the recession. In addition, voters may not fully account for delays in the economic effects of different types of reforms.

\section{Summing up}

We show that timing of reform is crucial in two senses: when reforms occur relative to the electoral cycle and when they occur relative to the business cycle. Voters do not seem to internalize the time that it takes for a reform to generate its effects on the economy. A liberalizing reform taken close to the next election is punished by the voters who do not see any immediate average benefit while losses from reforms may be visible. In these circumstances, we find that the vote share of the main governing party (or coalition) declines with liberalizing reforms implemented in the election year. This political cost disappears

\footnotetext{
${ }^{15}$ For example, the average magnitude of tightening reform in the election year in the data is only about onetwentieth of two standard deviations in the change of the indicator, and no major reform has occurred during extreme expansions with only one (Venezuela 1983) in an extreme recession.
} 
when reforms are implemented at the beginning of an Incumbent's term of office, and as such have enough time to generate their positive effects on the economy.

The state of the business cycle also influences the electoral effects of reforms. We show that when economies are in contractions, both liberalizing and tightening reforms are penalized at the ballot box. In contrast, reforms undertaken during a growth expansion are not punished electorally, and in some cases, are even rewarded. Voters seem to not be able to distinguish well enough between the effects of the business cycle and of the reform and appear to attribute the current state of the economy to the action taken by the government at that time, without allowing for the delays in effects of the reforms on the economy.

\section{ENDOGENEITY}

Governments can sometimes choose when to implement reforms. We say “sometimes" because the literature on policy reform (for instance Alesina and Drazen, 1991) shows that often the timing of reform is determined by the resolution of a political struggle, involving complex and long parliamentary impasses; or reforms are imposed by an economic crisis. Governments in some settings also have choices about when to call elections. These considerations lead to possible endogeneity in the relationship between reform and election outcomes as a government might delay unpalatable reforms until after elections or a government may be re-elected despite having implemented reforms because it chooses to reform when it is especially popular for other reasons. This endogeneity might generate an upward bias in the electoral rewards from reform if the government can choose when and whether to reform.

To explore this issue, we proceed in two ways. First, we distinguish between reforms which are externally mandated and not solely the choice of a national government. To do so, we re-estimate equation (3) augmented with the interaction between the reform indicator and a dummy variable that is equal to 1 for reforms implemented during IMF programs, and zero otherwise. Note that this approach assumes that reforms implemented outside an IMF program do not have political costs. As a result, this identification strategy could introduce an 'attenuation' bias and underestimate the impact of IMF mandated reforms on the vote share. 
Second, we use an instrumental variable proposed by Giuliano et al. (2013) and applied in a different context by Acemoglu et al. (2019) to examine the effect of democracy on long-term output. The estimation strategy relies on previous theoretical and empirical evidence that economic reforms are driven by democratic transitions. ${ }^{16}$ As in Giuliano et al. (2013), the instrument is the weighted average of the change in the democracy indicator in trading partners over the last two years, where the weights are determined by the strength of trade linkages with other countries. The first stage estimates suggest that this instrument is "strong" and statistically significant. The Kleibergen-Paap rk Wald F statistic - which is equivalent to the F-effective statistic for non-homoskedastic error in case of one endogenous variable and one instrument (Andrews et al., 2019)—is higher than the associated Stock-Yogo critical value. In addition, we can plausibly consider the instrument to be exogenous, since changes in democratic institutions in trading-partner countries are unlikely to be correlated with the error term of Equation (3)—regressions of the residuals from Equation (3) against the instrument support this claim. ${ }^{17}$

Another endogeneity issue concerns the timing of elections. In many countries, elections may be called early by leaders or legislative bodies. Exogenous elections correspond to about 40 percent (127 out of 327) of overall elections in our sample. The timing of an election could be correlated with economic conditions or with the popularity of the incumbent, creating a bias in our estimates. We address this issue by focusing on countries/time periods with exogenous elections - that is, those for which the head of government does not have the power to dissolve a parliament and call new elections.

\section{A. Results}

Tables 9 to 11 report our results. The qualitative patterns of the OLS regression results reported in Tables 4-8 are confirmed in these three specifications. Table 9 shows that the estimated effects of reforms on vote shares obtained with the IV approach, or limiting to

\footnotetext{
${ }^{16}$ See Milner and Mukerhjee (2008) and Giuliano et al. (2013) for a review.

17 The estimates are $\widehat{\varepsilon_{l t}}=0.171-0.829 * I_{i t}$,

where $I_{i t}$ denote the instrument, and t-statistics are reported in parenthesis.
} 
the case of exogenously-imposed reforms, or cases in which the timing of elections is fixed, are much larger than the ones obtained with OLS (column (I) in Table 9, which reprints the OLS results in column (I) in Table 6). This finding confirms that politicians may decide not to implement reforms because they are aware of possible political costs - which in our framework implies a downward bias of the OLS coefficient estimates. The coefficients on the other control variables remain stable.

Table 10 confirms the results regarding the electoral cost of election year reforms occurring mostly when the election year is in a recession. The distinction between reforms implemented in recessions and in expansions is not precisely estimated for IMF-imposed reforms. The reason is that most IMF-imposed reforms occur during recessions - that is, countries are more likely to request IMF support when they are in a difficult economic situation (see Table A1).

The results in Table 11 confirm the results presented in Table 8 when distinguishing between liberalizing and tightening reforms and their timings relative to the business cycle. In this table, we do not include IMF-imposed reforms because there are only a handful of cases of non-liberalizing reforms imposed by the IMF in addition to having very few IMF mandated reforms in an expansionary period. ${ }^{18}$

\section{EXTENSIONS}

In this section we explore several extensions. We examine whether the effect of reforms on electoral outcomes varies: (i) across types of reforms; (ii) between coalition and single party governments; (iii) between advanced and developing economies; (iv) between majoritarian and proportional systems; and (v) between old and new democracies.

The cases (ii)-(v) are tested by extending the baseline specification as follows:

\footnotetext{
${ }^{18}$ We report these results in Table A3. It is important to note that while the effects reported are economically large, they also portrait hypothetical situations that never occurred, such as a major tightening reform of two standard deviations of the change in the indicator in periods of major recession or expansion and IMF program.
} 
$\Delta$ Incumbent Party Vote Share $_{i, t}=\beta_{0}+\beta_{1}^{A} D *$ Reform $_{e y_{i, t-1}}+\beta_{2}^{A} D *$

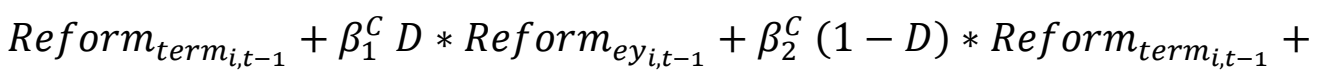

$\beta_{3}$ Growth $_{\text {ey }_{i, t-1}}+\beta_{4}$ Growth $_{\text {term }}$ fit-1 $_{1}+\beta_{4}$ Developed Country $_{i}+\beta_{5}$ NewDemocracy $_{i, t}+$

$\beta_{6}$ Majoritarian system $_{i, t}+\beta_{7}$ Initial Regulation $_{i, t-x}+$

$\beta_{8}$ Incumbent Party Vote Share $_{i, t-1}+\varepsilon_{i, t}$

where $D$ is a dummy variable as described below for each analysis. Equation (5) is estimated using OLS as well for the three strategies we use to mitigate endogeneity concerns. We further extend Equation (5) to examine the electoral effect of reforms for the cases (i)-(v) during periods of recessions and expansions. ${ }^{19}$

\section{A. Results}

\section{Types of reform}

We estimate equation (2) to differentiate the effect of financial sector reforms (Domestic Finance, Capital, and Financial Current) and the other domestic sector reforms (Trade, Product and Labor markets). The results show that while the effect of financial sector reforms on the vote share is large and statistically significant, the effect of real sector reform is not statistically significantly different from zero (Table 12). Similar results are obtained when estimating each reform separately (Table A4). Table A5 extends the financial versus real sector analysis to reversals and liberalizations, demonstrating that only financial reforms in recessions during election years harm incumbent electoral prospects. One potential explanation for this result is that financial sector reforms may be especially prone to engender increased income inequality (see, for example, de Han and Sturm, 2017; Furceri and Loungani, 2018; Ostry et al., 2018; Furceri et al., 2019).

In addition, we find some evidence that in bad times, both financial and real sector reforms are associated with lower incumbent's vote shares (Table A6). In contrast, in good times, real sector reforms tend to have a positive effect, but the coefficients are not always

\footnotetext{
${ }^{19}$ The results are reported in Table A6 and A8 of the Appendix.
} 
statistically significant at standard levels of confidence ${ }^{20}$ In other words, real sector reforms enacted in good times may help governments be re-elected. These results are again consistent with voters being unable to distinguish between the expected future long-run growth effects of reform and economic performance due to the underlining economic conditions at the time of the reform.

\section{Coalition vs. single party government}

We expect that the electoral penalty for reforms will fall largely on either the party governing alone or the majority party in a coalition. To test for this prediction, we estimate a specification analogous to equation (5), in which $D$ is a dummy variable that takes a value of 1 when the government is governing alone, and zero otherwise. The results suggest that the effect of reforms on the incumbent majority party's vote share is three times larger when the party is governing alone than when governing in a coalition (Table 13 (I)), and particularly so during recessions (Table A8 (I)). This is consistent with prior findings in the literature on "clarity of responsibility" (Powel and Whitten, 1993).

\section{Advanced vs. developing economies}

To test whether the effect of reforms varies across countries, we estimate a specification analogous to equation (5), in which $D$ is a dummy variable that takes the value of 1 for countries defined as advanced according to the IMF classification and 0 otherwise (Table 2). The results presented in Table 14 suggest that the effect is larger and more precisely estimated in developing economies than in advanced economies. ${ }^{21}$ The difference between advanced and developing, however, is statistically significant only for the IV

\footnotetext{
${ }^{20}$ This is especially the case for product market reforms (Table A6).

${ }^{21}$ In addition, we find that while reforms implemented in bad times are associated with lower vote share in developing economies, no statistically-significant difference between recessions and expansions emerges for advanced economies (Table A8).
} 
specification (III). In this table we do not include the IMF imposed reforms specification since there are very few IMF programs in advanced countries. ${ }^{22}$

\section{New vs. old democracies}

Brender and Drazen $(2005,2008)$ find evidence that budget deficits reduce the probability of reelection in new democracies, but not in old democracies. In the same spirit, we test whether the electoral effect of reforms varies between these two groups. We use the Brender-Drazen classification of "new democracies" ${ }^{23}$ (see Table 2 for the list of countries). The results in Table 15, obtained by estimating a specification analogous to equation (5) with D a dummy variable that takes the value of 1 for a new democracy, do not provide clear-cut evidence that the estimated effects are systematically larger for new democracies. Governments in both new and old democracies tend to be electorally penalized after implementing reforms.

\section{Majoritarian vs. proportional systems}

Finally, we test whether the effect of reforms varies between majoritarian and proportional systems. As shown in the baseline specification in Table 4, the coefficient for the majoritarian dummy is positive and statistically-significant, suggesting that majoritarian systems see more swings in the vote share. This may also imply that the electoral effects of reform tend to be amplified in these systems. To test for this possibility, we estimate a specification like equation (5), in which $D$ is a dummy variable that takes the value of 1 for majoritarian systems, and zero otherwise. The results presented in Table 16 suggest that the effect of reforms is larger and more precisely estimated in proportional systems than in majoritarian ones. The difference, however, is not statistically significant-in this table we do not include the IMF-imposed reforms specification since there are very few IMF

\footnotetext{
${ }^{22}$ We report the results in Table A7.

${ }^{23}$ Brender and Drazen $(2005,2008)$ classified new democracies using a dummy variable that takes value 1 for the first four elections after a year with a negative Polity score on the -10 to 10 scale, and 0 otherwise.
} 
programs in majoritarian systems. In addition, for both majoritarian and proportional systems, reforms are particularly costly during recessions (Table A8 (IV)).

\section{Conclusions}

We offer two new datasets: a comprehensive global dataset of regulation and major reforms and reversal events that covers a large sample of advanced and developing economies over almost half a century; and an election outcomes dataset. These databases offer many opportunities to scholars and policymakers for future research.

We explore the electoral consequences of structural reform policy changes in democratic countries. The electoral costs and benefits of reform depend on the nature (sector) and direction (liberalizing or reversal) of the reform and the timing of reforms relative to the electoral and economic cycles. Our results are consistent with a hypothesis that voters do not internalize the lag between the implementation of a reform and its economic effects. In addition, we find evidence suggesting that they attribute the current state of the economy at least in part to reforms implemented at the same time. Thus, when reforms occur during a recession, voters attribute overall economic conditions at least in part to the reform and turn against the incumbent. The cost of liberalizing reforms during recessions is especially large when they occur in an election year. When reforms occur during expansions, voters do not punish and may reward the incumbent. These results are robust across different types of electoral system, new and old democracies, and developing and developed countries. We also investigated in a variety of ways the issue of endogeneity of the timing of reforms relative to elections and our results seem robust.

The policy implication is that the best time for a government to implement reforms is at the beginning of its term of office and when the economy is in expansion. However, for both political and economic reasons, often governments cannot optimally choose the timing of reforms. 


\section{References}

Abiad, Abdul, and Ashoka Mody. 2005. "Financial Reform: What Shakes It? What Shapes It?” American Economic Review 95(1): 66-88.

Abiad, Abdul, Enrica Detragiache, and Thierry Tressel. 2009. “A New Database of Financial Reforms.” IMF Working Papers 08/266, International Monetary Fund, Washington, DC.

Acemoglu, Daron, Suresh Naidu, Pascual Restrepo, and James A. Robinson. 2019. “Democracy Does Cause Growth.” Journal of Political Economy 127(1): 47-100.

Alesina, Alberto, and Allan Drazen. 1991. “Why are stabilizations delayed?” American Economic Review 81(5): 1170-1188.

Alesina, Alberto, Gabriele Ciminelli, Davide Furceri, and Giorgio Saponaro. 2019a. “Austerity and Elections.” IMF Working Papers (forthcoming), International Monetary Fund, Washington, DC.

Alesina, Alberto, Carlo Favero, and Francesco Giavazzi. 2019b. Austerity: When It Works and When It Doesn't. Princeton, NJ: Princeton University Press.

Andrews, Isaiah, James Stock, and Liyang Sun. 2019. "Weak Instruments in IV Regression: Theory and Practice.” Annual Review of Economics (forthcoming).

Auerbach, Alan, and Youri Gorodnichenko. 2012. "Measuring the Output Responses to Fiscal Policy.” American Economic Journal: Economic Policy 4 (2): 1-27

Auerbach, Alan J., and Yuriy Gorodnichenko. 2013. "Fiscal Multipliers in Recession and Expansion.” In Fiscal Policy after the Financial Crisis, edited by Alberto Alesina and Francesco Giavazzi. Chicago, IL: University of Chicago Press, 63-98.

Autor, David H., David Dorn, Gordon H. Hanson, and Kaveh Majlesi. 2016. "Importing Political Polarization? The Electoral Consequences of Rising Trade Exposure.” MIT Working Paper (forthcoming), Massachusetts Institute of Technology, Cambridge, MA.

Barattieri, Alessandro, Matteo Cacciatore, and Fabio Ghironi. 2018. "Protectionism and the Business Cycle.” NBER Working Paper No. 24353, National Bureau of Economic Research, Cambridge, MA.

Bassanini, Andrea, and Federico Cingano. 2018. "Before It Gets Better: The Short-term Employment Costs of Regulatory Reforms.” International Labor Relations Review, March.

Bekaert, Geert, Campbell R. Harvey, and Christian Lundblad. 2005. "Does Financial Liberalization Spur Growth?” Journal of Financial Economics 77(1): 3-55.

Blanchard, Olivier and Francesco Giavazzi. 2003. "Macroeconomic Effects of Regulaton and Deregulation in Goods and Labor Markets.” Quarterly Journal of Economics 118 (3): 879-907.

Botero, Juan C., Simeon Djankov, Rafael La Porta, Florencio Lopez-de-Silanes, and Andrei Shleifer. 2004. “The Regulation of Labor.” The Quarterly Journal of Economics 119(4): 1339-1382. 
Brancati, Dawn. 2013. Global Elections Database [computer file]. New York: Global Elections Database [distributor].

Brender, Adi, and Allan Drazen. 2005. "Political Budget Cycles in New versus Established Democracies.” Journal of Monetary Economics 52(7): 1271-95.

Brender, Adi, and Allan Drazen. 2008. "How Do Budget Deficits and Economic Growth Affect Reelection Prospects?: Evidence from a Large Panel of Countries." American Economic Review 98(5): 2203-2220.

Buti, Marco, Pietro Biroli, Mathias Thoenig, Alesandro Turrini, Paul Van den Noord, and Ekaterina Zhuravskaya. 2010. "Reforms and Re-elections in OECD Countries." Economic Policy 25(61): 61-116.

Cacciatore, Matteo, Romain Duval, Giuseppe Fiori, and Fabio Ghironi. 2016. "Shortterm Pain for Long-Term Gain: Market Deregulation and Monetary Policy in Small Open Economies.” Journal of International Money and Finance 68: 35885.

Campos, Nauro F., and Jeffrey B. Nugent. 2012. "The Dynamics of the Regulation of Labor in Developing and Developed Countries since 1960." IZA Discussion Papers No. 6881, Institute of Labor Economics, Bonn, Germany.

Carr, Adam. 2019. Psephos: Adam Carr's Election Archive. http://psephos.adam-carr.net/ Center for Systemic Peace. 2016. The Polity Project. http://www.systemicpeace.org/polityproject.html.

Che, Yi, Yi Lu, Justin R. Pierce, Peter Schott, and Zhigang Tao. 2016. "Does Trade Liberalization with China Influence U.S. Elections?” NBER Working Paper No. 22178, National Bureau of Economic Research, Cambridge, MA.

Chinn, Menzie D., and Hiro Ito. 2008. “A New Measure of Financial Openness.” Journal of Comparative Policy Analysis 10(3): 309-22.

Cruz, Cesi, Philip Keefer, and Carlos Scartascini. 2016. "Database of Political Institutions Codebook, 2015 Update (DPI2015).” Inter-American Development Bank.

De Haan, Jakob, and Jan-Egbert Sturm. 2017. "Finance and Income Inequality: A Review and New Evidence.” European Journal of Political Economy 50: 171-195.

Dreher, Axel. 2004. "The Influence of IMF Programs on the Re-election of Debtor Governments." Economics and Politics 16(1): 53-75.

Duval, Romain, and Davide Furceri. 2018. "The Effects of Labor and Product Market Reforms: The Role of Macroeconomic Conditions and Policies.” IMF Economic Review 66(1): 31-69.

Election Results Archive. 2019. Election Results Archive (ERA). https://www.binghamton.edu/cdp/era15.html

Fair, Ray. 1978. The Effect of Economic Events on Votes for President, The Review of Economics and Statistics 60(2): 159-73. 
Feigenbaum, James J., and Andrew B. Hall. 2015. "How Legislators Respond to Localized Economic Shocks: Evidence from Chinese Import Competition.” Journal of Politics 77(4): 1012-1030.

Fernandez, Andres, Michael Klein, Alessandro Rebucci, Martin Schindler, and Martin Uribe. 2016. “Capital Control Measures: A New Dataset.” IMF Economic Review 64(3): 548-574.

Furceri, Davide, and Prakash Loungani. 2018. "The distributional effects of capital account liberalization.” Journal of Development Economics 130: 127-144.

Furceri, Davide, Prakash Loungani, and Jonathan D. Ostry. 2019. "The Aggregate and Distributional Effects of Financial Globalization: Evidence from Macro and Sectoral Data.” Journal of Money, Credit and Banking 51(S1): 163-198.

Furceri, Davide, Swarnali A. Hannan, Jonathan D. Ostry, and Andrew K. Rose. 2018. "Macroeconomic Consequences of Tariffs." No. 25402, National Bureau of Economic Research, Cambridge, MA.

Giuliano, Paola, Prachi Mishra, and Antonio Spilimbergo. 2013. "Democracy and Reforms: Evidence from a New Dataset.” American Economic Journal: Macroeconomics 5(4): 179-204.

Granger, Clive W. J., and Timo Teräsvirta. 1993. Modelling Nonlinear Economic Relationships. New York: Oxford University Press.

Haggard, Stefan, and Steven B. Webb. 1994. Voting for Reform: Democracy, Political Liberalization and Economic Adjustment. New York: Oxford University Press.

Henry, Peter Blair. 2007. "Capital Account Liberalization: Theory, Evidence, and Speculation.” Journal of Economic Literature 45(4): 887-935.

Kramer, Gerald H. 1977. “A Dynamical Model of Political Equilibrium.” Journal of Economic Theory 16(2): 310-334.

Jensen, J. Bradford, Dennis P. Quinn, and Steven Weymouth. 2017. "Winners and Losers in International Trade: The Effects on U.S. Presidential Voting.” International Organization 71(3): 423-457.

Jordà, Òscar. 2005. "Estimation and Inference of Impulse Responses by Local Projections.” American Economic Review 95(1): 161-182.

Lewis-Beck, Michael S., and Charles Tien. 2008. "Forecasting Presidential Elections: When to Change the Model.” International Journal of Forecasting 24(2): 227236.

Margalit, Yotam. 2011. "Costly Jobs: Trade-Related Layoffs, Government Compensation, and Voting in U.S. Elections.” American Political Science Review 105(1): 166-188.

Marshall, Monty G., Ted Gurr, and Keith Jaggers. 2017. "Polity IV Project: Political Regime Characteristics and Transitions, 1800-2016 (Dataset Users’ Manual).” Center for Systemic Peace. 
Milner, Helen V., and Bumba Mukherjee. 2009. “Democratization and Economic Globalization.” Annual Review of Political Science 12: 163-181.

Ortiz de Zárate, Roberto. 2019. ZPC: World Political Leaders. Zárate's Political Collections. http://zarate.eu/countries.html

Ostry, Jonathan D., Alessandro Prati, and Antonio Spilimbergo. 2009. "Structural Reforms and Economic Performance in Advanced and Developing Countries.” IMF Occasional Paper 268, International Monetary Fund, Washington, DC.

Ostry, Jonathan D., Andrew Berg, and Siddharth Kothari. 2018. "Growth-Equity Trade-offs in Structural Reforms.” IMF Working Papers 18/5, International Monetary Fund, Washington, DC.

Pacek, Alexander C. 1994. "Macroeconomic Conditions and Electoral Politics in East Central Europe.” American Journal of Political Science 38(3): 723-744.

Powell, G. Bingham, and Guy D. Whitten. 1993. "A Cross-National Analysis of Economic Voting: Taking Account of the Political Context.” American Journal of Political Science 37 (2):391-414.

Prati, Alessandro, Massimiliano G. Onorato, and Chris Papageorgiou. 2013. "Which Reforms Work and Under What Institutional Environment? Evidence from a New Data Set on Structural Reforms.” Review of Economics and Statistics 95(3): 946968.

Quinn, Dennis. 1997. “The Correlates of Change in International Financial Regulation.” American Political Science Review 91(3): 531-551.

Quinn, Dennis P., and A. Maria Toyoda. 2008. "Does Capital Account Liberalization Lead to Growth?” Review of Financial Studies 21(3): 1403-1449.

Quinn, Dennis P., and John T. Woolley. 2001. "Democracy and National Economic Performance: The Preference for Stability.” American Journal of Political Science 45(3): 634-657.

Ramey, Valerie A., and Sarah Zubairy. 2018. "Government Spending Multipliers in Good Times and in Bad: Evidence from U.S. Historical Data.” Journal of Political Economy 126(2): 850-901.

Scartascini, Carlos, Cesi Cruz, and Philip Keefer. 2018. "Database of Political Institutions 2017.” The Inter-American Development Bank.

Sturzenegger, Federico, and Mariano Tommasi. 1998. The Political Economy of Reform. Cambridge, MA: MIT University Press.

Tressel, Thierry, and Enrica Detragiache. 2008. "Do Financial Sector Reforms Lead to Financial Development? Evidence from a New Dataset.” IMF Working Papers 08/265, International Monetary Fund, Washington, DC.

Tufte, Edward R. 1978. Political Control of the Economy. Princeton, NJ: Princeton University Press. 
Weyland, Kurt. 1998. "Swallowing the Bitter Pill: Sources of Popular Support for Neoliberal Reform in Latin America." Comparative Political Studies 31(5): 539568. 
Figure 1. Stylized facts on reform progress
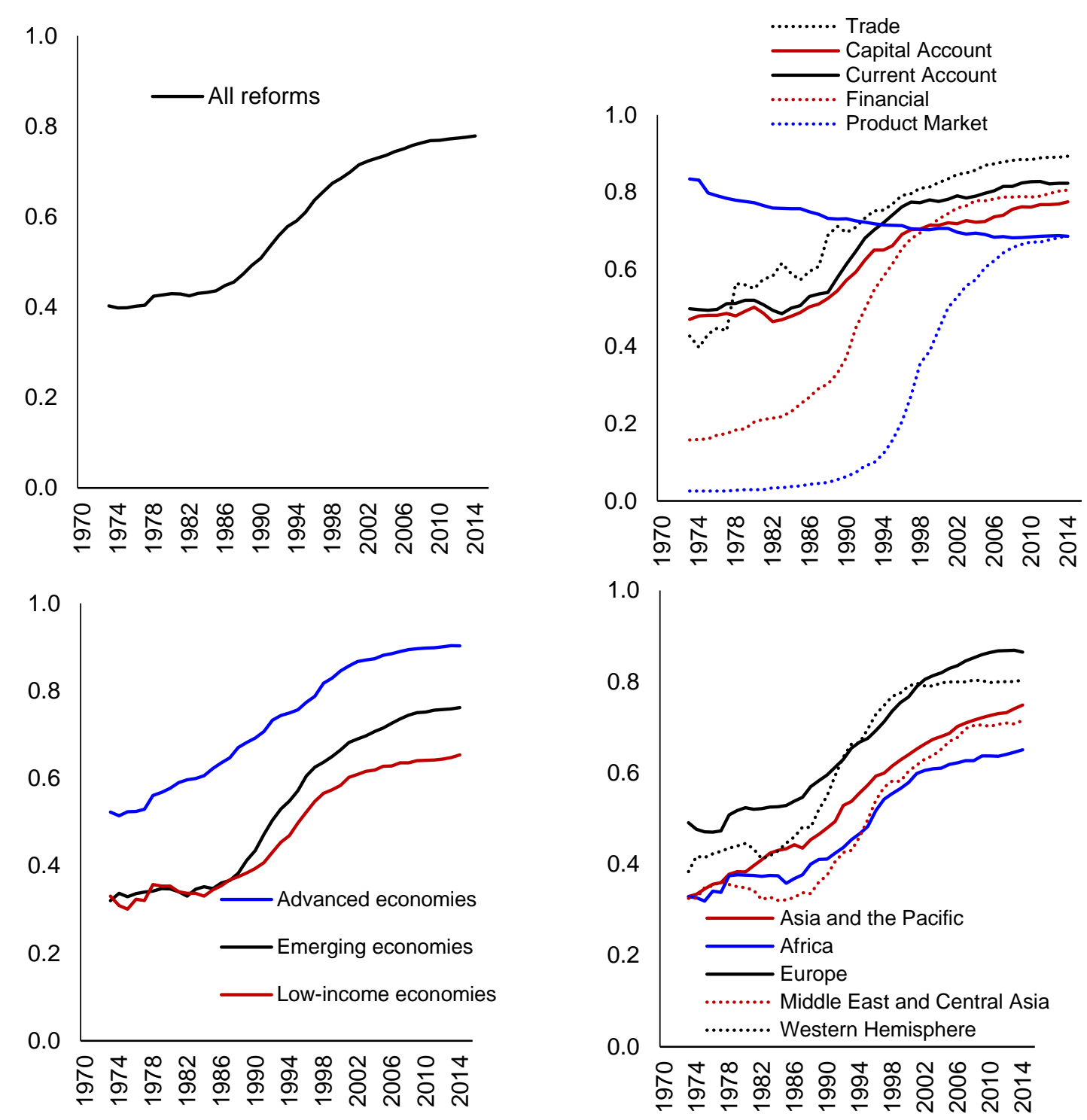

Note:the indicators ranges from 0 to 1 . Higher levels denote more liberlization. 
Figure 2. Macroeconomic effects of reform—output effect (\%)

2.5

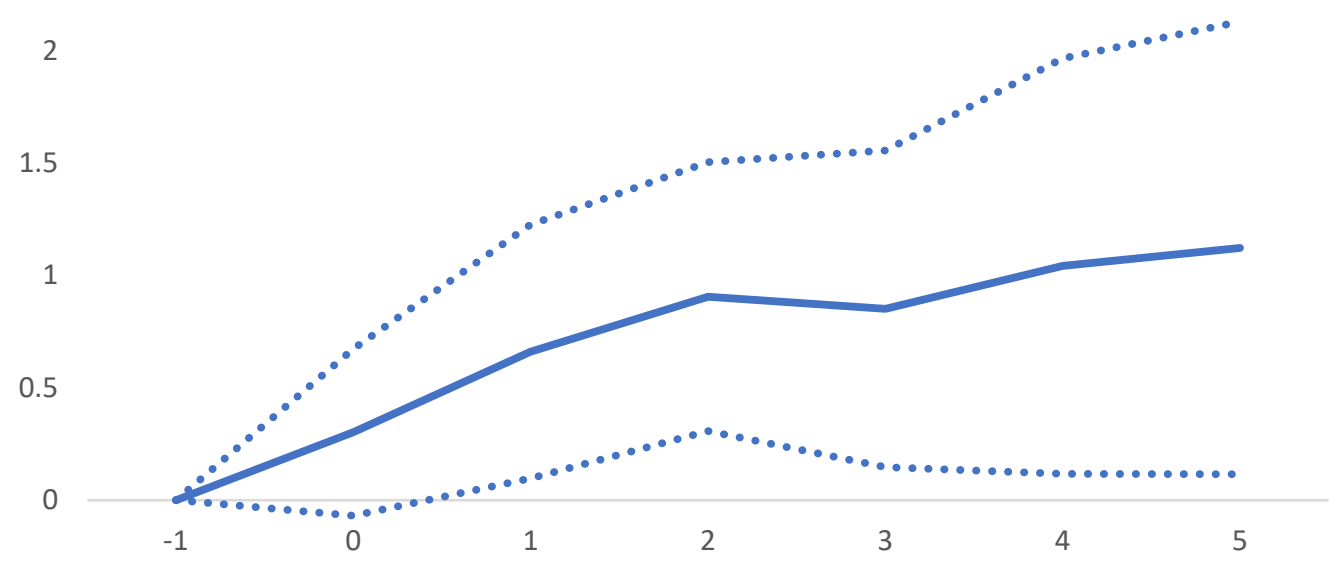

$-0.5$

Note: Output effects estimated using equation (1). $t=0$ is the year of the reform; solid lines denote the response of output to a major reform event, defined as a change of two standard deviations in the reform indicator. Dotted lines denote 95 percent confidence bands.

Figure 3. Macroeconomic effects of reform—output effect of liberalizing and tightening reforms (\%)

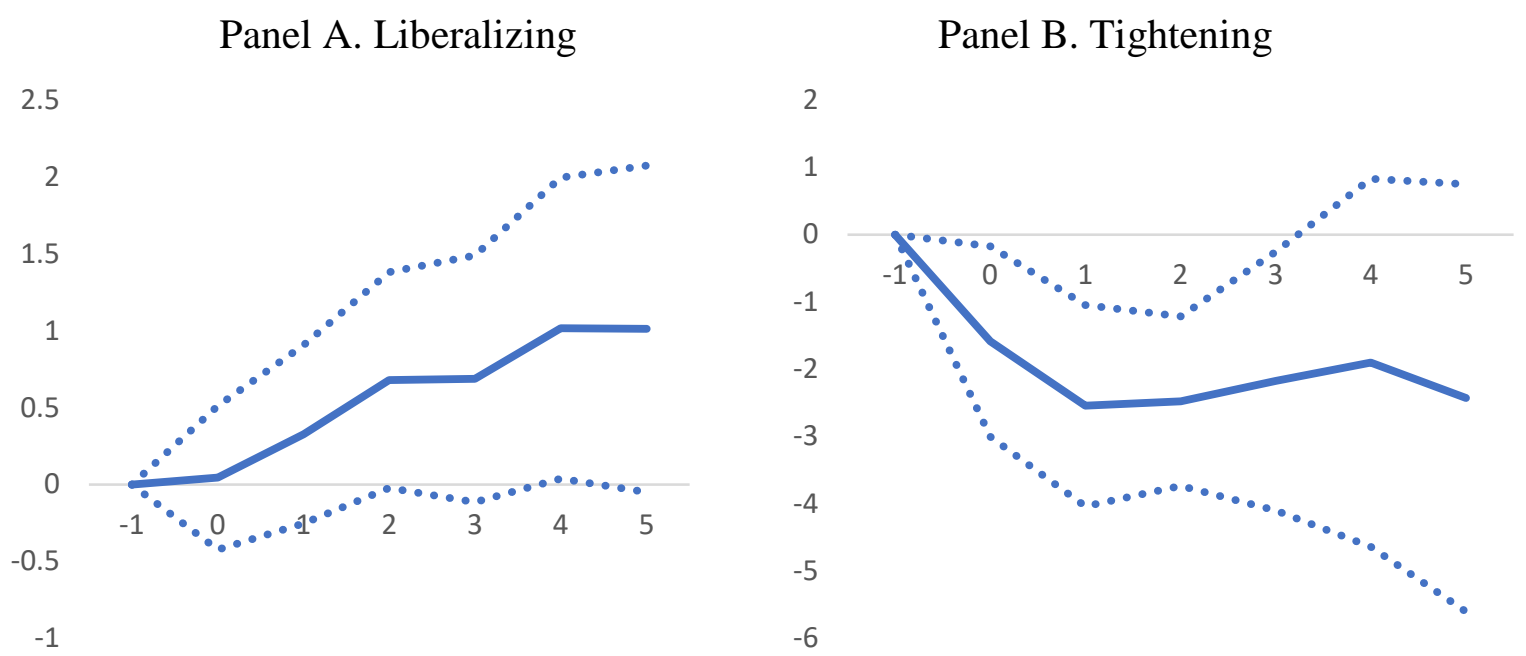

Note: Output effects estimated using equation (1). $t=0$ is the year of the reform; solid lines denote the response of output to a major reform event, defined as a change of two standard deviations in the reform indicator. Dotted lines denote 95 percent confidence bands. 
Figure 4. Macroeconomic effects of reform-output effect of liberalizing and tightening reforms depending on economic conditions (\%)

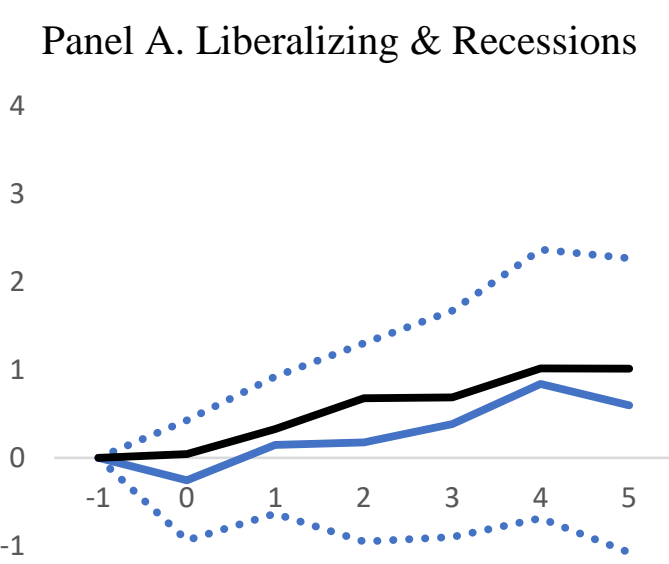

$-2$

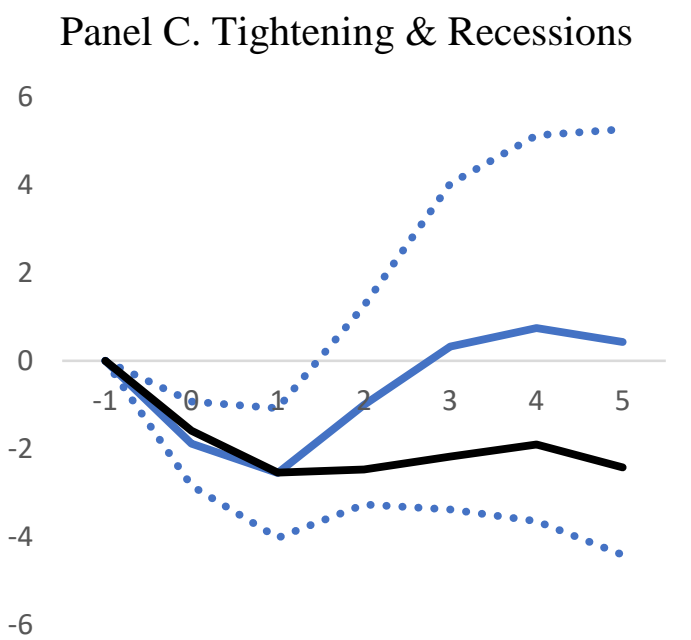

\section{Panel B. Liberalizing \& Expansions}

4

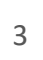

3

2

1

0

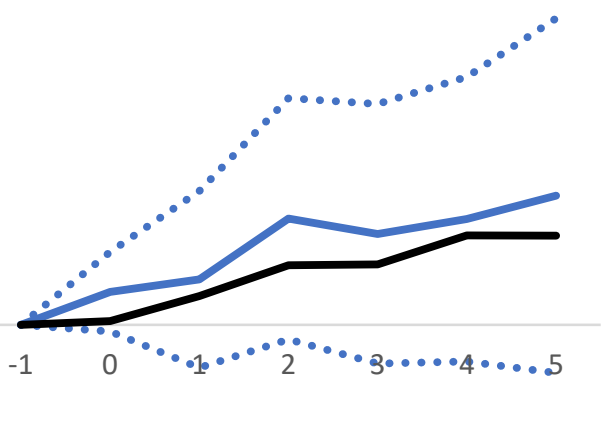

Note: Output effects estimated using equation (2). $t=0$ is the year of the reform; solid blue lines denote the response of output to a major reform event, defined as a change of two standard deviations in the reform indicator, in recessions and expansions. Solid black lines denote the unconditional effects reported in Figure 3. Dotted lines denote 95 percent confidence bands. 
Table 1. Reform dataset country coverage

\begin{tabular}{|l|ll|l|}
\hline \multicolumn{1}{|c|}{ Advanced economies } & \multicolumn{2}{|c|}{ Emerging markets } & Low income countries \\
\hline Australia & Albania & Namibia & Bangladesh \\
Austria & Algeria & Pakistan & Bolivia \\
Belgium & Argentina & Paraguay & Burkina Faso \\
Canada & Azerbaijan & Peru & Cameroon \\
Czech Republic & Belarus & Philippines & Côte d'Ivoire \\
Denmark & Botswana & Poland & Ethiopia \\
Estonia & Brazil & Romania & Ghana \\
Finland & Bulgaria & Russia & Kenya \\
France & Chile & South Africa & Kyrgyz Republic \\
Germany & China & Sri Lanka & Lesotho \\
Greece & Colombia & Swaziland & Madagascar \\
Hong Kong SAR & Costa Rica & Thailand & Malawi \\
Ireland & Dominican Republic & Tunisia & Mozambique \\
Israel & Ecuador & Turkey & Nepal \\
Italy & Egypt & Ukraine & Nicaragua \\
Japan & El Salvador & Uruguay & Nigeria \\
Korea & Georgia & Venezuela & Senegal \\
Latvia & Guatemala & & Tanzania \\
Netherlands & Hungary & & Uganda \\
New Zealand & India & & Uzbekistan \\
Norway & Indonesia & & Vietnam \\
Portugal & Jamaica & & Zambia \\
Singapore & Jordan & & \\
Spain & Kazakhstan & & \\
Sweden & Lithuania & & \\
Switzerland & Malaysia & & \\
United Kingdom & Mexico & & \\
United States & Morocco & & \\
\hline
\end{tabular}


Table 2. Election dataset coverage

\begin{tabular}{|c|c|c|c|c|c|c|c|}
\hline $\begin{array}{l}\text { Country } \\
\text { Name }\end{array}$ & $\begin{array}{c}\text { Years } \\
\text { Covered }\end{array}$ & $\begin{array}{c}\text { No. of } \\
\text { Elections }\end{array}$ & $\begin{array}{c}\text { Leg. } \\
\text { Elections }\end{array}$ & $\begin{array}{c}\text { Pre. } \\
\text { Elections }\end{array}$ & $\begin{array}{c}\text { Dev. } \\
\text { economy }\end{array}$ & Maj & New dem. \\
\hline Albania & 1996-2013 & 6 & $\mathrm{x}$ & & & & 1996-2013 \\
\hline Argentina & 1989-2011 & 6 & & $\mathrm{x}$ & & & 1989-2003 \\
\hline Australia & $1974-2013$ & 16 & $\mathrm{x}$ & & $\mathrm{x}$ & & \\
\hline Austria & $1975-2013$ & 12 & $\mathrm{x}$ & & $\mathrm{x}$ & & 1975-1986 \\
\hline Belgium & $1974-2010$ & 12 & $\mathrm{x}$ & & $\mathrm{x}$ & & \\
\hline Bolivia & 1985-2009 & 7 & & $\mathrm{x}$ & & & 1985-1997 \\
\hline Brazil & $1989-2010$ & 6 & & $\mathrm{x}$ & & & $1989-2002$ \\
\hline Bulgaria & 2001-2009 & 3 & $\mathrm{x}$ & & & & 2001-2009 \\
\hline Canada & $1974-2011$ & 12 & $\mathrm{x}$ & & $\mathrm{x}$ & $\mathrm{x}$ & \\
\hline Chile & $1993-2013$ & 5 & & $\mathrm{x}$ & & $\mathrm{x}$ & 1993-2009 \\
\hline Colombia & $1974-2010$ & 10 & & $\mathrm{x}$ & & & 1974-1986 \\
\hline Costa Rica & $1974-2010$ & 10 & & $\mathrm{x}$ & & & \\
\hline $\begin{array}{l}\text { Czech } \\
\text { Republic }\end{array}$ & 1996-2006 & 3 & $\mathrm{x}$ & & $\mathrm{x}$ & & 1996-2006 \\
\hline Denmark & $1975-2011$ & 14 & $\mathrm{x}$ & & $\mathrm{x}$ & & $1975-1979$ \\
\hline $\begin{array}{l}\text { Dominican } \\
\text { Rep. }\end{array}$ & 1978-2012 & 10 & & $\mathrm{x}$ & & & 1978-2012 \\
\hline Ecuador & $1984-2013$ & 9 & & $\mathrm{x}$ & & & 1984-1996 \\
\hline El Salvador & 1989-2009 & 5 & & $\mathrm{x}$ & & & $1989-2004$ \\
\hline Estonia & 1992-2011 & 6 & $\mathrm{x}$ & & $\mathrm{x}$ & $\mathrm{x}$ & \\
\hline Finland & $1979-2011$ & 9 & $\mathrm{x}$ & & $\mathrm{x}$ & & 1979-1991 \\
\hline France & $1974-2012$ & 7 & & $\mathrm{x}$ & $\mathrm{x}$ & $\mathrm{x}$ & $1974-1988$ \\
\hline Georgia & $1995-2013$ & 3 & & $\mathrm{x}$ & $\mathrm{x}$ & & \\
\hline Germany & $1976-2013$ & 11 & $\mathrm{x}$ & & & & 1976-1987 \\
\hline Ghana & $2000-2012$ & 4 & & $\mathrm{x}$ & & $\mathrm{x}$ & $2000-2012$ \\
\hline Greece & 1977-2009 & 10 & $\mathrm{x}$ & & $\mathrm{x}$ & & 1977-1989 \\
\hline Guatemala & $1990-2011$ & 6 & & $\mathrm{x}$ & & & $1990-2011$ \\
\hline Hungary & 1994-2006 & 4 & $\mathrm{x}$ & & & & $1994-2006$ \\
\hline India & $1977-2009$ & 10 & $\mathrm{x}$ & & & & \\
\hline Indonesia & 2004-2014 & 2 & & $\mathrm{x}$ & & & 2004-14 \\
\hline Ireland & $1977-2011$ & 11 & $\mathrm{x}$ & & $\mathrm{x}$ & & \\
\hline Israel & $1981-2013$ & 11 & $\mathrm{x}$ & & $\mathrm{x}$ & & \\
\hline Italy & $1976-2013$ & 9 & $\mathrm{x}$ & & $\mathrm{x}$ & & 1976-1987 \\
\hline Jamaica & $1976-2011$ & 9 & $\mathrm{x}$ & & & $\mathrm{x}$ & \\
\hline Japan & $1976-2012$ & 13 & $\mathrm{x}$ & & $\mathrm{x}$ & & 1976-1986 \\
\hline Kenya & $2002-2013$ & 3 & & $\mathrm{x}$ & & $\mathrm{x}$ & $2002-2013$ \\
\hline Kyrgyzstan & 2009-2011 & 2 & & $\mathrm{x}$ & & & 2009-2011 \\
\hline Latvia & $1993-2011$ & 7 & $\mathrm{x}$ & & $\mathrm{x}$ & & \\
\hline Lithuania & $1997-2009$ & 3 & & $\mathrm{x}$ & $\mathrm{x}$ & & \\
\hline Madagascar & $1996-2006$ & 3 & & $\mathrm{x}$ & & & 1996-2006 \\
\hline Malaysia & $1974-2013$ & 10 & $\mathrm{x}$ & & & $\mathrm{x}$ & \\
\hline Mexico & $1988-2012$ & 5 & & $\mathrm{x}$ & & & 1994-2012 \\
\hline $\begin{array}{l}\text { Mozambiqu } \\
\text { e }\end{array}$ & 1994-2014 & 4 & & $\mathrm{x}$ & & & 1994-2014 \\
\hline Nepal & 1991-2008 & 4 & $\mathrm{x}$ & & & $\mathrm{x}$ & 1991-2008 \\
\hline
\end{tabular}




\begin{tabular}{|c|c|c|c|c|c|c|c|}
\hline Netherlands & $1977-2012$ & 12 & $\mathrm{x}$ & & $\mathrm{x}$ & & 1977-1986 \\
\hline $\begin{array}{l}\text { New } \\
\text { Zealand }\end{array}$ & $1975-2011$ & 13 & $\mathrm{X}$ & & $\mathrm{x}$ & $\mathrm{x}$ & \\
\hline Nicaragua & $1990-2011$ & 5 & & $\mathrm{x}$ & & & 1996-2011 \\
\hline Nigeria & 1983-2015 & 4 & & $\mathrm{x}$ & & $\mathrm{x}$ & 1983-2015 \\
\hline Norway & $1977-2013$ & 10 & $\mathrm{x}$ & & $\mathrm{X}$ & & \\
\hline Paraguay & 1993-2013 & 5 & & $\mathrm{x}$ & & & 1998-2008 \\
\hline Peru & 1985-2011 & 6 & & $\mathrm{x}$ & & & 1985-2011 \\
\hline Philippines & $1992-2010$ & 4 & & $\mathrm{x}$ & & $\mathrm{x}$ & $1992-2010$ \\
\hline Poland & $1995-2010$ & 4 & & $\mathrm{x}$ & & & $1995-2010$ \\
\hline Portugal & 1980-2011 & 11 & $\mathrm{x}$ & & $\mathrm{x}$ & & 1983-1991 \\
\hline Romania & 1996-2012 & 4 & $\mathrm{x}$ & & & & 1996-2012 \\
\hline Senegal & 2007-2012 & 2 & & $\mathrm{x}$ & & & 2007-2012 \\
\hline South Africa & 1987-2009 & 6 & & $\mathrm{x}$ & & & 1994-2014 \\
\hline South Korea & $1992-2012$ & 5 & & $\mathrm{x}$ & $\mathrm{x}$ & & $1992-2007$ \\
\hline Spain & 1979-2011 & 10 & $\mathrm{x}$ & & $\mathrm{x}$ & & 1979-1993 \\
\hline Sri Lanka & $1982-2010$ & 6 & & $\mathrm{x}$ & & & \\
\hline Sweden & $1976-2010$ & 11 & $\mathrm{x}$ & & $\mathrm{x}$ & & 1973-1982 \\
\hline Thailand & $1995-2011$ & 5 & $\mathrm{x}$ & & & $\mathrm{x}$ & $1995-2011$ \\
\hline Turkey & $1977-2011$ & 8 & $\mathrm{x}$ & & & & 1977-1999 \\
\hline Ukraine & 1994-2010 & 3 & & $\mathrm{x}$ & & $\mathrm{x}$ & \\
\hline $\begin{array}{l}\text { United } \\
\text { Kingdom }\end{array}$ & $1974-2010$ & 10 & $\mathrm{x}$ & & $\mathrm{X}$ & $\mathrm{x}$ & \\
\hline $\begin{array}{l}\text { United } \\
\text { States }\end{array}$ & 1976-2012 & 10 & & $\mathrm{x}$ & $\mathrm{X}$ & $\mathrm{x}$ & \\
\hline Uruguay & 1989-2009 & 5 & & $\mathrm{x}$ & & & 1989-2004 \\
\hline Venezuela & 1978-2006 & 7 & & $\mathrm{x}$ & & & 1973-1988 \\
\hline
\end{tabular}

Table 3. Reforms in the electoral cycle (\% of one standard deviation)

\begin{tabular}{lccc}
\hline & All & $\begin{array}{c}\text { Weak economic } \\
\text { conditions }\end{array}$ & $\begin{array}{c}\text { Strong economic } \\
\text { conditions }\end{array}$ \\
\hline Reform_ey & 0.410 & 0.432 & 0.381 \\
Reform_ey (+) & 0.491 & 0.503 & 0.474 \\
Reversal_ey (-) & -0.072 & -0.065 & -0.081 \\
Reform_term & 0.628 & 0.687 & 0.555 \\
Reform_term (+) & 0.680 & 0.729 & 0.620 \\
Reversal_term (-) & -0.043 & -0.037 & -0.049 \\
\hline
\end{tabular}

Note: Reform_ey and Reform_term denote reforms in the election year and in the rest of the incumbent leader term, respectively. Reform (+) and Reversal (-) denote liberalization and tightening reforms, respectively. Weak and strong economic conditions are defined as in equation (2). 
Table 4. The effect of reforms on electoral outcomes-election year

\begin{tabular}{|c|c|c|c|c|}
\hline & (I) & (II) & (III) & (IV) \\
\hline \multirow[t]{2}{*}{ Reform_ey } & $-2.770 * * *$ & $-3.187 * *$ & $-3.496 * *$ & $-2.721 * *$ \\
\hline & [0.915] & [1.263] & [1.321] & [1.278] \\
\hline \multirow[t]{2}{*}{ Initial level regulation } & -5.097 & 1.563 & 23.375 & 13.669 \\
\hline & [5.910] & [10.561] & [33.409] & [17.134] \\
\hline \multirow[t]{2}{*}{ Growth_ey } & $0.516 * *$ & 0.373 & 0.260 & 0.171 \\
\hline & {$[0.206]$} & {$[0.267]$} & {$[0.410]$} & [0.429] \\
\hline \multirow[t]{2}{*}{ Growth_term } & 0.411 & $0.692 *$ & $0.834 *$ & 0.748 \\
\hline & [0.320] & [0.394] & [0.487] & [0.497] \\
\hline \multirow[t]{2}{*}{ Advanced economy } & $3.409 * * *$ & & & \\
\hline & [1.235] & & & \\
\hline \multirow[t]{2}{*}{ New democracies } & 0.837 & 0.146 & 0.310 & -0.033 \\
\hline & [1.117] & [2.240] & [3.990] & [4.018] \\
\hline \multirow[t]{2}{*}{ Majoritarian system } & $2.314^{* *}$ & 4.763 & $10.350^{* *}$ & $11.147 * * *$ \\
\hline & {$[0.940]$} & [4.141] & [4.021] & [4.113] \\
\hline \multirow[t]{2}{*}{ Lagged vote share } & -0.146 & $-0.242 * *$ & $-0.265^{*}$ & $-0.265^{*}$ \\
\hline & {$[0.093]$} & [0.103] & {$[0.137]$} & [0.135] \\
\hline \multirow[t]{2}{*}{ Budget } & & & & 0.153 \\
\hline & & & & {$[0.267]$} \\
\hline \multirow[t]{2}{*}{ Inflation } & & & & $-0.006 *$ \\
\hline & & & & {$[0.003]$} \\
\hline Country fixed effects & No & Yes & Yes & Yes \\
\hline Country-specific time trends & No & No & Yes & Yes \\
\hline $\mathrm{R} 2$ & 0.10 & 0.27 & 0.47 & 0.48 \\
\hline Observations & 327 & 327 & 327 & 327 \\
\hline
\end{tabular}

Note: Reform_ey denotes reforms in the election year. Estimates based on equation (3). Standard deviations based on robust standard errors in parentheses. $* * *, * *, *$ denote significance at 1,5 and 10 percent, respectively. 
Table 5. The effect of reforms on electoral outcomes-rest of term

\begin{tabular}{|c|c|c|c|c|}
\hline & (I) & (II) & (III) & (IV) \\
\hline \multirow[t]{2}{*}{ Reform_term } & -0.400 & -0.413 & 0.825 & -0.060 \\
\hline & [1.088] & [1.173] & [1.432] & {$[1.743]$} \\
\hline \multirow[t]{2}{*}{ Initial level regulation } & -1.095 & 5.845 & 32.619 & 29.353 \\
\hline & [6.210] & [10.042] & {$[35.431]$} & [37.351] \\
\hline \multirow[t]{2}{*}{ Growth_ey } & $0.468 * *$ & 0.299 & 0.167 & 0.081 \\
\hline & {$[0.201]$} & {$[0.255]$} & [0.417] & [0.423] \\
\hline \multirow[t]{2}{*}{ Growth_term } & 0.488 & $0.784^{*}$ & $0.878 *$ & 0.781 \\
\hline & {$[0.327]$} & {$[0.406]$} & [0.484] & [0.506] \\
\hline \multirow[t]{2}{*}{ Advanced economy } & $3.275^{* *}$ & & & \\
\hline & [1.243] & & & \\
\hline \multirow[t]{2}{*}{ New democracies } & 0.766 & 0.248 & 1.331 & 0.437 \\
\hline & {$[1.176]$} & {$[2.243]$} & [3.889] & [3.883] \\
\hline \multirow[t]{2}{*}{ Majoritarian system } & $2.303^{* *}$ & 4.396 & $10.057 * *$ & $10.067 * *$ \\
\hline & [0.992] & [3.977] & {$[4.430]$} & {$[4.810]$} \\
\hline \multirow[t]{2}{*}{ Lagged vote share } & -0.149 & $-0.229 * *$ & $-0.249 *$ & $-0.255^{*}$ \\
\hline & {$[0.092]$} & {$[0.104]$} & [0.138] & [0.133] \\
\hline \multirow[t]{2}{*}{ Budget } & & & & 0.163 \\
\hline & & & & {$[0.251]$} \\
\hline \multirow[t]{2}{*}{ Inflation } & & & & $-0.008 * * *$ \\
\hline & & & & {$[0.003]$} \\
\hline Country fixed effects & No & Yes & Yes & Yes \\
\hline Country-specific time trends & No & No & Yes & Yes \\
\hline $\mathrm{R}^{2}$ & 0.08 & 0.25 & 0.46 & 0.47 \\
\hline Observations & 327 & 327 & 327 & 327 \\
\hline
\end{tabular}

Note: Reform_term denote reforms in the rest of the incumbent leader term. Estimates based on equation (3).

Standard deviations based on robust standard errors in parentheses. ${ }^{* * *}, * *, *$ denote significance at 1,5 and 10 percent, respectively. 
Table 6. The effect of reforms on electoral outcomes—election year vs. rest of term

\begin{tabular}{|c|c|c|c|c|}
\hline & (I) & (II) & (III) & (IV) \\
\hline \multirow[t]{2}{*}{ Reform_ey } & $-2.820 * * *$ & $-3.230 * *$ & $-3.460 * *$ & $-2.725 * *$ \\
\hline & [0.947] & [1.295] & [1.327] & [1.279] \\
\hline \multirow[t]{2}{*}{ Reform_term } & -0.672 & -0.656 & 0.354 & -0.137 \\
\hline & [1.040] & [1.170] & [1.398] & [1.687] \\
\hline \multirow[t]{2}{*}{ Initial level regulation } & -6.798 & -0.981 & 26.900 & 26.035 \\
\hline & [6.009] & {$[10.376]$} & [35.584] & [36.605] \\
\hline \multirow[t]{2}{*}{ Growth_ey } & $0.512 * *$ & 0.362 & 0.260 & 0.171 \\
\hline & {$[0.206]$} & [0.265] & [0.410] & {$[0.431]$} \\
\hline \multirow[t]{2}{*}{ Growth_term } & 0.425 & $0.699 *$ & $0.826^{*}$ & 0.751 \\
\hline & [0.323] & [0.398] & {$[0.486]$} & {$[0.495]$} \\
\hline \multirow[t]{2}{*}{ Advanced economy } & $3.474 * * *$ & & & \\
\hline & [1.245] & & & \\
\hline \multirow[t]{2}{*}{ New democracies } & 0.804 & -0.036 & 0.380 & -0.063 \\
\hline & [1.109] & [2.187] & [3.950] & [3.981] \\
\hline \multirow[t]{2}{*}{ Majoritarian system } & $2.293 * *$ & 4.376 & $10.865^{* *}$ & $10.944^{* *}$ \\
\hline & [0.923] & [4.164] & [4.585] & {$[4.811]$} \\
\hline \multirow[t]{2}{*}{ Lagged vote share } & -0.146 & $-0.243 * *$ & $-0.264 *$ & $-0.265^{*}$ \\
\hline & [0.093] & [0.103] & [0.137] & {$[0.134]$} \\
\hline \multirow[t]{2}{*}{ Budget } & & & & 0.152 \\
\hline & & & & {$[0.266]$} \\
\hline \multirow[t]{2}{*}{ Inflation } & & & & $-0.006^{*}$ \\
\hline & & & & {$[0.003]$} \\
\hline Country fixed effects & No & Yes & Yes & Yes \\
\hline Country-specific time trends & No & No & Yes & Yes \\
\hline $\mathrm{R}^{2}$ & 0.10 & 0.27 & 0.47 & 0.48 \\
\hline Observations & 327 & 327 & 327 & 327 \\
\hline
\end{tabular}

Note: Reform_ey and Reform_term denote reforms in the election year and in the rest of the incumbent leader term, respectively. Estimates based on equation (3). Standard deviations based on robust standard errors in parentheses. ***,**,* denote significance at 1,5 and 10 percent, respectively. 
Table 7. The effect of reforms on electoral outcomes-recessions vs. expansions

\begin{tabular}{|c|c|c|c|}
\hline & (I) & (II) & (III) \\
\hline \multirow[t]{2}{*}{ Reform_ey (recessions) } & $-4.092 * *$ & & $-4.250 * *$ \\
\hline & [1.563] & & [1.598] \\
\hline \multirow[t]{2}{*}{ Reform_ey (expansions) } & -1.201 & & -1.338 \\
\hline & {$[1.870]$} & & [1.917] \\
\hline \multirow[t]{2}{*}{ Reform_term (recessions) } & & -0.010 & -1.583 \\
\hline & & {$[2.520]$} & [1.985] \\
\hline \multirow[t]{2}{*}{ Reform_term (expansions) } & & -0.772 & 0.150 \\
\hline & & {$[2.570]$} & {$[2.345]$} \\
\hline \multirow[t]{2}{*}{ Initial level regulation } & -4.759 & -1.090 & -6.709 \\
\hline & {$[6.037]$} & {$[6.221]$} & [5.992] \\
\hline \multirow[t]{2}{*}{ Growth_ey } & $0.474 * *$ & $0.465 * *$ & $0.478 * *$ \\
\hline & {$[0.214]$} & {$[0.201]$} & {$[0.215]$} \\
\hline \multirow[t]{2}{*}{ Growth_term } & 0.415 & 0.503 & 0.391 \\
\hline & [0.321] & [0.365] & [0.352] \\
\hline \multirow[t]{2}{*}{ Advanced economy } & $3.341^{* * *}$ & $3.281 * *$ & $3.400 * * *$ \\
\hline & [1.227] & [1.249] & [1.229] \\
\hline \multirow[t]{2}{*}{ New democracies } & 0.821 & 0.785 & 0.746 \\
\hline & [1.124] & {$[1.156]$} & [1.107] \\
\hline \multirow[t]{2}{*}{ Majoritarian system } & $2.210^{* *}$ & $2.294 * *$ & $2.208^{* *}$ \\
\hline & {$[0.960]$} & {$[0.994]$} & {$[0.930]$} \\
\hline \multirow[t]{2}{*}{ Lagged vote share } & -0.144 & -0.149 & -0.144 \\
\hline & {$[0.094]$} & [0.092] & {$[0.094]$} \\
\hline Total effect recessions & $-4.092 * *$ & -0.010 & $-5.833 * * *$ \\
\hline Total effect expansions & -1.201 & -0.772 & -1.433 \\
\hline F-test difference & 0.34 & 0.87 & 1.02 \\
\hline $\mathrm{R}^{2}$ & 0.10 & 0.08 & 0.10 \\
\hline Observations & 327 & 327 & 327 \\
\hline
\end{tabular}

Note: Reform_ey and Reform_term denote reforms in the election year and in the rest of the incumbent leader term, respectively. Estimates based on equation (4). Standard deviations based on robust standard errors in parentheses. $* * *, * *, *$ denote significance at 1,5 and 10 percent, respectively. 
Table 8. The effect of reforms on electoral outcomes—Reforms vs. Reversals

\begin{tabular}{|c|c|c|}
\hline & $\begin{array}{c}\text { (I) } \\
\text { Baseline }\end{array}$ & $\begin{array}{c}\text { (II) } \\
\text { Recessions vs. expansions }\end{array}$ \\
\hline Reform_ey (+) & $\begin{array}{c}-2.930 * * \\
{[1.157]}\end{array}$ & \\
\hline Reversal_ey (-) & $\begin{array}{c}2.575 \\
{[3.025]}\end{array}$ & \\
\hline Reform_term $(+)$ & $\begin{array}{l}-0.397 \\
{[1.061]}\end{array}$ & \\
\hline Reversal_term (-) & $\begin{array}{c}2.245 \\
{[4.071]}\end{array}$ & \\
\hline Reform_ey (+) (recessions) & & $\begin{array}{c}-4.196 * * \\
{[1.663]}\end{array}$ \\
\hline Reversal_ey (-) (recessions) & & $\begin{array}{c}0.618 \\
{[2.690]}\end{array}$ \\
\hline Reform_term (+) (recessions) & & $\begin{array}{l}-4.658^{*} \\
{[2.349]}\end{array}$ \\
\hline Reversal_term (-) (recessions) & & $\begin{array}{c}-12.643 * * * \\
{[3.871]}\end{array}$ \\
\hline Reform_ey (+) (expansions) & & $\begin{array}{c}-0.286 \\
{[1.993]}\end{array}$ \\
\hline Reversal_ey (-) (expansions) & & $\begin{array}{c}7.286 \\
{[10.955]}\end{array}$ \\
\hline Reform_term $(+)$ (expansions) & & $\begin{array}{l}3.413^{*} \\
{[1.845]}\end{array}$ \\
\hline Reversal_term (-) (expansions) & & $\begin{array}{c}20.442 * * * \\
{[6.280]}\end{array}$ \\
\hline F-test: Reform_ey (+) vs. (-) & 0.92 & 0.83 \\
\hline Total effect recessions & & $-5.833 * * *$ \\
\hline Total effect expansions & & -1.433 \\
\hline F-test difference & & 1.02 \\
\hline $\begin{array}{l}\mathrm{R}^{2} \\
\text { Observations }\end{array}$ & $\begin{array}{l}0.10 \\
327\end{array}$ & $\begin{array}{l}0.13 \\
327\end{array}$ \\
\hline
\end{tabular}

Note: Reform_ey and Reform_term denote reforms in the election year and in the rest of the incumbent leader term, respectively. Reform (+) and Reversal (-) denote liberalization and tightening reforms, respectively.

Estimates based on equation (5). Additional controls in the baseline specifications are included but not reported. Standard deviations based on robust standard errors in parentheses. ${ }^{* * *}, * *, *$ denote significance at 1,5 and 10 percent, respectively. 
Table 9. The effect of reforms on electoral outcomes—exogeneity checks

\begin{tabular}{|c|c|c|c|c|}
\hline & (I) & (II) & (III) & (IV) \\
\hline & OLS & Ex. elections & & \\
\hline \multirow[t]{2}{*}{ Reform_ey } & $-2.820 * * *$ & $-3.966 * * *$ & $-5.109 * *$ & $-7.672 * * *$ \\
\hline & [0.947] & [1.043] & [2.143] & [1.584] \\
\hline \multirow[t]{2}{*}{ Reform_term } & -0.672 & -0.596 & -1.248 & -1.140 \\
\hline & [1.040] & [2.096] & [2.449] & [1.047] \\
\hline \multirow[t]{2}{*}{ Initial level regulation } & -6.798 & -4.399 & -1.482 & $-16.611^{* *}$ \\
\hline & [6.009] & [14.615] & [5.954] & {$[7.487]$} \\
\hline \multirow[t]{2}{*}{ Growth_ey } & $0.512 * *$ & $0.502^{*}$ & $0.502 * *$ & $0.586 * * *$ \\
\hline & {$[0.206]$} & [0.269] & {$[0.208]$} & {$[0.222]$} \\
\hline \multirow[t]{2}{*}{ Growth_term } & 0.425 & $1.191^{* *}$ & 0.445 & 0.316 \\
\hline & [0.323] & [0.568] & {$[0.313]$} & {$[0.341]$} \\
\hline \multirow[t]{2}{*}{ Advanced economy } & $3.474 * * *$ & 4.948 & $2.776^{* *}$ & $3.815^{* * *}$ \\
\hline & [1.245] & [2.985] & [1.321] & {$[1.281]$} \\
\hline \multirow[t]{2}{*}{ New democracies } & 0.804 & 1.713 & 1.114 & 0.870 \\
\hline & [1.109] & [2.253] & [1.127] & [1.039] \\
\hline \multirow[t]{2}{*}{ Majoritarian system } & $2.293^{* *}$ & 0.536 & $2.131 * *$ & $2.275^{* * *}$ \\
\hline & [0.923] & [2.480] & [0.999] & {$[0.856]$} \\
\hline \multirow[t]{2}{*}{ Lagged vote share } & -0.146 & -0.009 & -0.135 & -0.141 \\
\hline & {$[0.093]$} & {$[0.121]$} & {$[0.094]$} & {$[0.093]$} \\
\hline Kleibergen-Paap rk Wald F statistic & & & & 25.92 \\
\hline Stock-Yogo $10 \%$ critical value & & & & 16.38 \\
\hline (Uncentered) $\mathrm{R}^{2}$ & 0.10 & 0.14 & 0.09 & 0.23 \\
\hline Observations & 327 & 127 & 327 & 327 \\
\hline
\end{tabular}

Note: Reform_ey and Reform_term denote reforms in the election year and in the rest of the incumbent leader term, respectively. Estimates based on equation (3). Standard deviations based on robust standard errors in parentheses. $* * *, * *, *$ denote significance at 1,5 and 10 percent, respectively. 
Table 10. The effect of reforms on electoral outcomes-recessions vs. expansions, exogeneity checks

\begin{tabular}{|c|c|c|c|c|}
\hline & (I) & (II) & (III) & (IV) \\
\hline & OLS & Ex. elections & IMF & IV \\
\hline \multirow[t]{2}{*}{ Reform_ey (recessions) } & $-4.250 * *$ & $-5.362 * * *$ & -1.886 & $-7.357 * * *$ \\
\hline & {$[1.598]$} & [0.813] & {$[11.814]$} & [1.193] \\
\hline \multirow[t]{2}{*}{ Reform_ey (expansions) } & -1.338 & -1.441 & -6.893 & -0.093 \\
\hline & [1.917] & [4.201] & [4.811] & [1.690] \\
\hline \multirow[t]{2}{*}{ Reform_term (recessions) } & -1.583 & -2.465 & -2.293 & -2.193 \\
\hline & [1.985] & [3.424] & [3.667] & [1.954] \\
\hline \multirow[t]{2}{*}{ Reform_term (expansions) } & 0.150 & 1.043 & -0.474 & 0.474 \\
\hline & [2.345] & [4.531] & [5.353] & [2.269] \\
\hline \multirow[t]{2}{*}{ Initial level regulation } & -6.709 & -4.002 & -1.579 & -8.525 \\
\hline & [5.992] & [14.824] & [5.975] & [6.062] \\
\hline \multirow[t]{2}{*}{ Growth_ey } & $0.478 * *$ & 0.451 & $0.510 * *$ & $0.436^{*}$ \\
\hline & {$[0.215]$} & [0.295] & [0.208] & {$[0.225]$} \\
\hline \multirow[t]{2}{*}{ Growth_term } & 0.391 & $1.145^{*}$ & 0.428 & 0.357 \\
\hline & [0.352] & [0.572] & {$[0.311]$} & {$[0.353]$} \\
\hline \multirow[t]{2}{*}{ Advanced economy } & $3.400 * * *$ & 4.899 & $2.744^{* *}$ & $3.370 * * *$ \\
\hline & [1.229] & [2.981] & [1.327] & [1.209] \\
\hline \multirow[t]{2}{*}{ New democracies } & 0.746 & 1.519 & 1.090 & 0.712 \\
\hline & [1.107] & [2.433] & [1.143] & [1.074] \\
\hline \multirow[t]{2}{*}{ Majoritarian system } & $2.208 * *$ & 0.595 & $2.135 * *$ & $2.057 * *$ \\
\hline & [0.930] & [2.459] & {$[0.994]$} & {$[0.912]$} \\
\hline \multirow[t]{2}{*}{ Lagged vote share } & -0.144 & -0.002 & -0.137 & -0.139 \\
\hline & [0.094] & [0.123] & {$[0.094]$} & {$[0.091]$} \\
\hline Total effect recessions & $-5.833 * * *$ & $-7.827 * *$ & -4.178 & $-9.551 * * *$ \\
\hline Total effect expansions & -1.433 & -0.398 & -7.367 & 0.382 \\
\hline F-test difference & 1.02 & 0.96 & 0.03 & $4.51^{* *}$ \\
\hline Kleibergen-Paap rk Wald F statistic & & & & 184.4 \\
\hline Stock-Yogo $10 \%$ critical value & & & & 16.38 \\
\hline (Uncentered) $\mathrm{R}^{2}$ & 0.10 & 0.14 & 0.09 & 0.26 \\
\hline Observations & 327 & 127 & 327 & 327 \\
\hline
\end{tabular}

Note: Reform_ey and Reform_term denote reforms in the election year and in the rest of the incumbent leader term, respectively. Estimates based on equation (4). Standard deviations based on robust standard errors in parentheses. ***,**,* denote significance at 1,5 and 10 percent, respectively. 
Table 11. The effect of reforms on electoral outcomes—Reforms vs. Reversals

\begin{tabular}{|c|c|c|c|}
\hline & $\begin{array}{c}\text { (I) } \\
\text { OLS }\end{array}$ & $\begin{array}{c}\text { (II) } \\
\text { Ex. elections }\end{array}$ & $\begin{array}{c}\text { (III) } \\
\text { IV }\end{array}$ \\
\hline Reform_ey (+) (recessions) & $\begin{array}{c}-4.196 * * \\
{[1.663]}\end{array}$ & $\begin{array}{c}-5.620 * * * \\
{[1.880]}\end{array}$ & $\begin{array}{c}-6.623 * * * \\
{[1.191]}\end{array}$ \\
\hline Reversal_ey (-) (recessions) & $\begin{array}{c}0.618 \\
{[2.690]}\end{array}$ & $\begin{array}{c}1.679 \\
{[3.957]}\end{array}$ & $\begin{array}{c}-0.388 \\
{[2.859]}\end{array}$ \\
\hline Reform_term $(+)$ (recessions) & $\begin{array}{l}-4.658^{*} \\
{[2.349]}\end{array}$ & $\begin{array}{l}-4.701 \\
{[5.895]}\end{array}$ & $\begin{array}{c}-4.859 * * \\
{[2.233]}\end{array}$ \\
\hline Reversal_term (-) (recessions) & $\begin{array}{c}-12.643^{* * *} \\
{[3.871]}\end{array}$ & $\begin{array}{l}-5.675 \\
{[6.833]}\end{array}$ & $\begin{array}{c}-10.961^{* * *} \\
{[2.985]}\end{array}$ \\
\hline Reform_ey (+) (expansions) & $\begin{array}{c}-0.286 \\
{[1.993]}\end{array}$ & $\begin{array}{l}1.700 \\
{[4.827]}\end{array}$ & $\begin{array}{c}0.583 \\
{[1.656]}\end{array}$ \\
\hline Reversal_ey (-) (expansions) & $\begin{array}{c}7.286 \\
{[10.955]}\end{array}$ & $\begin{array}{c}13.680 \\
{[18.993]}\end{array}$ & $\begin{array}{c}7.934 \\
{[10.522]}\end{array}$ \\
\hline Reform_term $(+)$ (expansions) & $\begin{array}{l}3.413^{*} \\
{[1.845]}\end{array}$ & $\begin{array}{c}5.529 \\
{[3.829]}\end{array}$ & $\begin{array}{c}3.460 * * \\
{[1.764]}\end{array}$ \\
\hline Reversal_term (-) (expansions) & $\begin{array}{c}20.442 * * * \\
{[6.280]}\end{array}$ & $\begin{array}{c}17.341^{* * *} \\
{[6.833]}\end{array}$ & $\begin{array}{c}19.711 * * * \\
{[5.749]}\end{array}$ \\
\hline Initial level regulation & $\begin{array}{l}-6.097 \\
{[6.494]}\end{array}$ & $\begin{array}{c}-1.760 \\
{[14.667]}\end{array}$ & $\begin{array}{l}-7.717 \\
{[6.523]}\end{array}$ \\
\hline Growth_ey & $\begin{array}{l}0.457^{*} \\
{[0.246]}\end{array}$ & $\begin{array}{c}0.290 \\
{[0.354]}\end{array}$ & $\begin{array}{l}0.377^{*} \\
{[0.234]}\end{array}$ \\
\hline Growth_term & $\begin{array}{c}0.091 \\
{[0.365]}\end{array}$ & $\begin{array}{c}0.869 \\
{[0.751]}\end{array}$ & $\begin{array}{c}0.078 \\
{[0.354]}\end{array}$ \\
\hline Advanced economy & $\begin{array}{c}3.467 * * * \\
{[1.287]}\end{array}$ & $\begin{array}{l}5.237^{*} \\
{[2.881]}\end{array}$ & $\begin{array}{c}3.417 * * * \\
{[1.248]}\end{array}$ \\
\hline New democracies & $\begin{array}{c}1.311 \\
{[1.108]}\end{array}$ & $\begin{array}{c}2.427 \\
{[2.492]}\end{array}$ & $\begin{array}{c}1.285 \\
{[1.081]}\end{array}$ \\
\hline Majoritarian system & $\begin{array}{l}2.175^{* *} \\
{[0.963]}\end{array}$ & $\begin{array}{c}0.774 \\
{[2.392]}\end{array}$ & $\begin{array}{l}2.034 * * \\
{[0.937]}\end{array}$ \\
\hline Lagged vote share & $\begin{array}{c}-0.160 * \\
{[0.093]}\end{array}$ & $\begin{array}{l}-0.031 \\
{[0.128]}\end{array}$ & $\begin{array}{l}-0.154 * \\
{[0.089]}\end{array}$ \\
\hline Total effect recessions & $-20.879 * * *$ & -14.317 & $-22.831 * * *$ \\
\hline $\begin{array}{l}\text { Total effect expansions } \\
\text { F-test: difference }\end{array}$ & $\begin{array}{l}30.856 * * \\
11.95 * * *\end{array}$ & $\begin{array}{c}38.251^{* *} \\
4.77^{* *}\end{array}$ & $\begin{array}{l}31.688 * * \\
14.18 * * *\end{array}$ \\
\hline Kleibergen-Paap rk Wald F statistic & & & 293.32 \\
\hline $\begin{array}{l}\text { Stock-Yogo } 10 \% \text { critical value } \\
\text { (Uncentered) } \mathrm{R}^{2}\end{array}$ & 0.13 & 0.18 & $\begin{array}{c}16.38 \\
0.29\end{array}$ \\
\hline Observations & 327 & 127 & 327 \\
\hline
\end{tabular}

Note: Reform_ey and Reform_term denote reforms in the election year and in the rest of the incumbent leader term, respectively. Reform (+) and Reversal (-) denote liberalization and tightening reforms, respectively. Estimates based on equation (5). Standard deviations based on robust standard errors in parentheses. ${ }^{* * *}, * *, *$ denote significance at 1,5 and 10 percent, respectively. 
Table 12. The effect of reforms on electoral outcomes-Finance vs. Real

\begin{tabular}{|c|c|c|c|c|c|c|c|c|}
\hline & \multicolumn{2}{|c|}{ OLS } & \multicolumn{2}{|c|}{$\begin{array}{cc}\text { (III) } & (\mathrm{IV}) \\
\text { Exogenous elections }\end{array}$} & \multicolumn{2}{|c|}{ IMF } & \multicolumn{2}{|r|}{ (7) } \\
\hline & Finance & Real & Finance & Real & Finance & Real & Finance & Real \\
\hline Reform_ey & $\begin{array}{c}-7.346^{* * *} \\
{[2.362]}\end{array}$ & $\begin{array}{c}1.712 \\
{[2.155]}\end{array}$ & $\begin{array}{c}-9.090 * * * \\
{[2.491]}\end{array}$ & $\begin{array}{c}7.776 \\
{[7.290]}\end{array}$ & $\begin{array}{c}-20.612^{* * *} \\
{[6.743]}\end{array}$ & $\begin{array}{c}11.987 \\
{[14.689]}\end{array}$ & $\begin{array}{c}-16.685^{* * *} \\
{[3.749]}\end{array}$ & $\begin{array}{c}0.297 \\
{[16.620]}\end{array}$ \\
\hline Reform_term & $\begin{array}{c}0.018 \\
{[2.557]}\end{array}$ & $\begin{array}{l}-1.257 \\
{[1.786]}\end{array}$ & $\begin{array}{c}4.427 \\
{[3.851]}\end{array}$ & $\begin{array}{l}-2.126 \\
{[4.096]}\end{array}$ & $\begin{array}{l}-1.886 \\
{[3.797]}\end{array}$ & $\begin{array}{c}-11.984^{*} \\
{[6.120]}\end{array}$ & $\begin{array}{l}-0.554 \\
{[2.464]}\end{array}$ & $\begin{array}{l}-1.174 \\
{[1.993]}\end{array}$ \\
\hline Initial level regulation & $\begin{array}{l}-3.049 \\
{[4.923]}\end{array}$ & $\begin{array}{l}-0.706 \\
{[6.225]}\end{array}$ & $\begin{array}{c}4.586 \\
{[8.902]}\end{array}$ & $\begin{array}{c}2.228 \\
{[14.795]}\end{array}$ & $\begin{array}{l}-1.553 \\
{[4.368]}\end{array}$ & $\begin{array}{l}-0.788 \\
{[6.150]}\end{array}$ & $\begin{array}{l}-7.655 \\
{[5.277]}\end{array}$ & $\begin{array}{c}-1.372 \\
{[10.184]}\end{array}$ \\
\hline Growth_ey & $\begin{array}{c}0.287 \\
{[0.256]}\end{array}$ & $\begin{array}{l}0.467 * * \\
{[0.199]}\end{array}$ & $\begin{array}{l}0.442^{*} \\
{[0.258]}\end{array}$ & $\begin{array}{c}0.414 \\
{[0.249]}\end{array}$ & $\begin{array}{c}0.319 \\
{[0.253]}\end{array}$ & $\begin{array}{l}0.493^{* *} \\
{[0.200]}\end{array}$ & $\begin{array}{c}0.299 \\
{[0.262]}\end{array}$ & $\begin{array}{l}0.473 * * \\
{[0.205]}\end{array}$ \\
\hline Growth_term & $\begin{array}{l}0.673 * * \\
{[0.311]}\end{array}$ & $\begin{array}{c}0.484 \\
{[0.326]}\end{array}$ & $\begin{array}{l}0.987 * * \\
{[0.454]}\end{array}$ & $\begin{array}{l}1.343^{* *} \\
{[0.528]}\end{array}$ & $\begin{array}{l}0.679 * * \\
{[0.314]}\end{array}$ & $\begin{array}{c}0.419 \\
{[0.318]}\end{array}$ & $\begin{array}{l}0.609^{*} \\
{[0.314]}\end{array}$ & $\begin{array}{c}0.483 \\
{[0.324]}\end{array}$ \\
\hline Advanced economy & $\begin{array}{c}3.298 * * * \\
{[1.217]}\end{array}$ & $\begin{array}{c}3.189 * * * \\
{[1.173]}\end{array}$ & $\begin{array}{l}4.124^{*} \\
{[2.232]}\end{array}$ & $\begin{array}{l}5.290^{*} \\
{[2.826]}\end{array}$ & $\begin{array}{l}2.519 * * \\
{[1.237]}\end{array}$ & $\begin{array}{l}2.603^{* *} \\
{[1.153]}\end{array}$ & $\begin{array}{c}3.698 * * * \\
{[1.230]}\end{array}$ & $\begin{array}{c}3.211^{* * *} \\
{[1.108]}\end{array}$ \\
\hline New democracies & $\begin{array}{c}0.739 \\
{[1.125]}\end{array}$ & $\begin{array}{c}0.668 \\
{[1.162]}\end{array}$ & $\begin{array}{c}1.188 \\
{[1.917]}\end{array}$ & $\begin{array}{c}1.385 \\
{[2.507]}\end{array}$ & $\begin{array}{c}1.163 \\
{[1.137]}\end{array}$ & $\begin{array}{c}1.022 \\
{[1.184]}\end{array}$ & $\begin{array}{c}0.742 \\
{[1.086]}\end{array}$ & $\begin{array}{c}0.708 \\
{[1.112]}\end{array}$ \\
\hline Majoritarian system & $\begin{array}{c}1.536 \\
{[1.042]}\end{array}$ & $\begin{array}{l}2.264 * * \\
{[1.015]}\end{array}$ & $\begin{array}{c}0.252 \\
{[2.158]}\end{array}$ & $\begin{array}{c}0.409 \\
{[2.797]}\end{array}$ & $\begin{array}{c}1.293 \\
{[1.030]}\end{array}$ & $\begin{array}{l}1.926^{*} \\
{[1.006]}\end{array}$ & $\begin{array}{c}1.528 \\
{[1.062]}\end{array}$ & $\begin{array}{l}2.280 * * \\
{[0.981]}\end{array}$ \\
\hline Lagged vote share & $\begin{array}{c}-0.182 * * \\
{[0.082]}\end{array}$ & $\begin{array}{c}-0.15 \\
{[0.091]}\end{array}$ & $\begin{array}{l}-0.027 \\
{[0.112]}\end{array}$ & $\begin{array}{c}-0.019 \\
{[0.113]}\end{array}$ & $\begin{array}{c}-0.176^{* *} \\
{[0.081]}\end{array}$ & $\begin{array}{l}-0.158 * \\
{[0.085]}\end{array}$ & $\begin{array}{c}-0.177^{* *} \\
{[0.081]}\end{array}$ & $\begin{array}{c}-0.149 * \\
{[0.090]}\end{array}$ \\
\hline $\begin{array}{l}\text { Kleibergen-Paap rk Wald F } \\
\text { statistic } \\
\text { Stock-Yogo } 10 \% \text { critical value }\end{array}$ & & & & & & & $\begin{array}{l}31.37 \\
16.38\end{array}$ & $\begin{array}{l}9.03 \\
16.38\end{array}$ \\
\hline $\begin{array}{l}\text { (Uncentered) } \mathrm{R}^{2} \\
\text { Observations }\end{array}$ & $\begin{array}{l}0.11 \\
363\end{array}$ & $\begin{array}{l}0.09 \\
327\end{array}$ & $\begin{array}{l}0.15 \\
140\end{array}$ & $\begin{array}{l}0.12 \\
127\end{array}$ & $\begin{array}{l}0.11 \\
363\end{array}$ & $\begin{array}{c}0.1 \\
327\end{array}$ & $\begin{array}{l}0.08 \\
363\end{array}$ & $\begin{array}{l}0.08 \\
327\end{array}$ \\
\hline
\end{tabular}

Note: Reform _ey and Reform_term denote reforms in the election year and in the rest of the incumbent leader term, respectively. Estimates based on equation (3). Standard deviations based on robust standard errors in parentheses. ${ }^{* * *}, * *, *$ denote significance at 1,5 and 10 percent, respectively. 
Table 13. The effect of reforms on electoral outcomes-Governing alone vs. coalition

\begin{tabular}{|c|c|c|c|c|}
\hline & $\begin{array}{c}\text { (I) } \\
\text { OLS }\end{array}$ & $\begin{array}{c}\text { (II) } \\
\text { Ex. elections }\end{array}$ & $\begin{array}{l}\text { (III) } \\
\text { IMF }\end{array}$ & $\begin{array}{c}\text { (IV) } \\
\text { IV }\end{array}$ \\
\hline \multirow[t]{2}{*}{ Reform_ey (Gov. alone) } & $-3.132 * * *$ & $-2.056 * * *$ & $-3.135^{* * *}$ & $-3.688 * * *$ \\
\hline & [1.033] & [0.507] & [1.112] & [0.769] \\
\hline \multirow[t]{2}{*}{ Reform_term (Gov. alone) } & -0.112 & -0.372 & 0.123 & -0.24 \\
\hline & [1.402] & [1.021] & [1.045] & {$[0.670]$} \\
\hline \multirow[t]{2}{*}{ Reform_ey (Gov. in coalition) } & -1.001 & 2.538 & 4.663 & -0.852 \\
\hline & [1.223] & [9.176] & [3.919] & [0.644] \\
\hline \multirow[t]{2}{*}{ Reform_term (Gov. in coalition) } & -1.723 & 1.981 & $-18.161 * * *$ & -1.252 \\
\hline & [1.479] & [7.787] & [5.435] & {$[0.773]$} \\
\hline \multirow[t]{2}{*}{ Initial level regulation } & -6.613 & -4.449 & -0.278 & $-14.448 * *$ \\
\hline & [5.940] & {$[14.821]$} & [5.874] & [6.966] \\
\hline \multirow[t]{2}{*}{ Growth_ey } & $0.514^{* *}$ & $0.490 *$ & $0.613 * * *$ & $0.573 * * *$ \\
\hline & {$[0.205]$} & [0.267] & {$[0.194]$} & {$[0.218]$} \\
\hline \multirow[t]{2}{*}{ Growth_term } & 0.437 & $1.214^{* *}$ & 0.446 & 0.359 \\
\hline & [0.318] & [0.564] & [0.296] & [0.319] \\
\hline \multirow[t]{2}{*}{ Advanced economy } & $3.509 * * *$ & 5.136 & $3.020 * *$ & $3.716^{* * *}$ \\
\hline & [1.241] & [3.105] & [1.296] & [1.264] \\
\hline \multirow[t]{2}{*}{ New democracies } & 0.729 & 1.766 & 0.993 & 0.814 \\
\hline & [1.143] & [2.243] & [1.096] & [1.057] \\
\hline \multirow[t]{2}{*}{ Majoritarian system } & $2.248^{* *}$ & 0.209 & $1.901 *$ & $2.344^{* * *}$ \\
\hline & [0.961] & {$[2.470]$} & {$[1.004]$} & {$[0.889]$} \\
\hline \multirow[t]{2}{*}{ Lagged vote share } & -0.146 & -0.015 & -0.11 & -0.141 \\
\hline & [0.093] & [0.118] & {$[0.092]$} & {$[0.093]$} \\
\hline Total effect (Gov. alone) & $-3.244 *$ & $-4.856 *$ & $-6.024 *$ & $-7.858 * * *$ \\
\hline Total effect (Gov. in coalition) & -2.724 & 9.038 & $-26.996 * * *$ & $-4.208 * *$ \\
\hline F-test: difference & 0.06 & 0.17 & $8.07 * * *$ & $3.00^{*}$ \\
\hline \multicolumn{5}{|l|}{ Kleibergen-Paap rk Wald F } \\
\hline statistic & & & & 25.85 \\
\hline Stock-Yogo $10 \%$ critical value & & & & 16.38 \\
\hline (Uncentered) $\mathrm{R}^{2}$ & 0.1 & 0.15 & 0.13 & 0.07 \\
\hline Observations & 327 & 128 & 327 & 327 \\
\hline
\end{tabular}

Note: Reform_ey and Reform_term denote reforms in the election year and in the rest of the incumbent leader term, respectively. Estimates based on equation (6). Standard deviations based on robust standard errors in parentheses. $* * *, * *, *$ denote significance at 1,5 and 10 percent, respectively. 
Table 14. The effect of reforms on electoral outcomes_Advanced vs. Developing Economies

\begin{tabular}{|c|c|c|c|}
\hline & $\begin{array}{c}\text { (I) } \\
\text { OLS }\end{array}$ & $\begin{array}{c}\text { (II) } \\
\text { Ex. elections }\end{array}$ & $\begin{array}{l}\text { (III) } \\
\text { IV }\end{array}$ \\
\hline \multirow[t]{2}{*}{ Reform_ey(Adv.) } & $-1.310^{*}$ & -8.991 & $-1.503 * *$ \\
\hline & {$[0.696]$} & [7.035] & {$[0.687]$} \\
\hline \multirow[t]{2}{*}{ Reform_ey(Dev.) } & $-4.075 * * *$ & $-3.711 * * *$ & $-7.651 * * *$ \\
\hline & [1.344] & [1.113] & {$[1.564]$} \\
\hline \multirow[t]{2}{*}{ Reform_term(Adv.) } & -0.79 & 0.786 & -1.058 \\
\hline & [1.030] & {$[5.423]$} & [1.047] \\
\hline \multirow[t]{2}{*}{ Reform_term(Dev.) } & -0.7 & -0.721 & -1.011 \\
\hline & [1.824] & [2.115] & [1.718] \\
\hline \multirow[t]{2}{*}{ Initial level regulation } & -6.835 & -4.255 & -10.993 \\
\hline & [6.083] & [15.681] & [6.815] \\
\hline \multirow[t]{2}{*}{ Growth_ey } & $0.511 * *$ & $0.510^{*}$ & $0.541^{* *}$ \\
\hline & {$[0.206]$} & {$[0.273]$} & {$[0.217]$} \\
\hline \multirow[t]{2}{*}{ Growth_term } & 0.406 & $1.217^{* *}$ & 0.339 \\
\hline & [0.322] & {$[0.578]$} & [0.323] \\
\hline \multirow[t]{2}{*}{ Advanced economy } & $2.944 * *$ & 4.94 & $2.398^{*}$ \\
\hline & [1.455] & [3.651] & [1.397] \\
\hline \multirow[t]{2}{*}{ New democracies } & 0.816 & 1.795 & 0.866 \\
\hline & [1.126] & [2.203] & [1.071] \\
\hline \multirow[t]{2}{*}{ Majoritarian system } & $2.253 * *$ & 0.43 & $2.193^{* *}$ \\
\hline & [0.962] & [2.532] & {$[0.956]$} \\
\hline \multirow[t]{2}{*}{ Lagged vote share } & -0.144 & -0.007 & -0.139 \\
\hline & {$[0.093]$} & [0.122] & [0.093] \\
\hline Total effect (Adv.) & -2.100 & -8.205 & $-2.561 *$ \\
\hline Total effect (Dev.) & $-4.775^{*}$ & -4.432 & $-8.662 * * *$ \\
\hline F-test: difference & 0.97 & 0.22 & $7.21^{* * *}$ \\
\hline Kleibergen-Paap rk Wald F statistic & & & 22.44 \\
\hline Stock-Yogo $10 \%$ critical value & & & 16.38 \\
\hline (Uncentered) $\mathrm{R}^{2}$ & 0.11 & 0.15 & 0.26 \\
\hline Observations & 327 & 127 & 327 \\
\hline
\end{tabular}

Note: Reform_ey and Reform_term denote reforms in the election year and in the rest of the incumbent leader term, respectively. Estimates based on equation (5). Standard deviations based on robust standard errors in parentheses. ***,**,* denote significance at 1,5 and 10 percent, respectively. 
Table 15. The effect of reforms on electoral outcomes—-new vs. old democracy

\begin{tabular}{|c|c|c|c|c|}
\hline & (I) & (II) & (III) & (IV) \\
\hline & OLS & Ex. elections & IMF & IV \\
\hline \multirow[t]{2}{*}{ Reform_ey(New dem.) } & $-3.871^{* * *}$ & $-4.030 * * *$ & $-6.774 * * *$ & $-6.354 * * *$ \\
\hline & [1.224] & [1.153] & [2.200] & [1.350] \\
\hline \multirow[t]{2}{*}{ Reform_ey(Old dem.) } & -1.529 & -1.854 & -2.017 & $-1.612^{*}$ \\
\hline & [1.007] & [3.919] & [3.692] & [0.981] \\
\hline \multirow[t]{2}{*}{ Reform_term((New dem.) } & 2.332 & 1.832 & $2.527 *$ & 1.881 \\
\hline & [1.538] & [2.093] & [1.361] & [1.457] \\
\hline \multirow[t]{2}{*}{ Reform_term(Old dem.) } & -2.248 & -3.968 & $-12.839 * *$ & -2.356 \\
\hline & [1.448] & [3.239] & [5.867] & [1.411] \\
\hline \multirow[t]{2}{*}{ Initial level regulation } & -7.601 & -4.596 & -1.252 & -9.206 \\
\hline & [6.228] & [15.009] & [5.880] & [6.250] \\
\hline \multirow[t]{2}{*}{ Growth_ey } & $0.531^{* *}$ & 0.465 & $0.556^{* * *}$ & $0.554^{* * *}$ \\
\hline & [0.208] & [0.278] & [0.199] & [0.213] \\
\hline \multirow{2}{*}{ Growth_term } & 0.346 & $1.060 *$ & 0.343 & 0.303 \\
\hline & {$[0.314]$} & [0.581] & {$[0.305]$} & [0.309] \\
\hline \multirow[t]{2}{*}{ Advanced economy } & $3.596 * * *$ & $5.208^{*}$ & $2.296^{*}$ & $3.622 * * *$ \\
\hline & {$[1.21]$} & {$[2.846]$} & [1.337] & [1.197] \\
\hline \multirow[t]{2}{*}{ New democracies } & -0.141 & 0.197 & 0.146 & 0.536 \\
\hline & {$[1.555]$} & [2.778] & [1.230] & [1.518] \\
\hline \multirow[t]{2}{*}{ Majoritarian system } & $2.219^{* *}$ & 0.449 & $1.844 *$ & $2.176^{* *}$ \\
\hline & [0.924] & [2.373] & [0.990] & [0.912] \\
\hline \multirow[t]{2}{*}{ Lagged vote share } & -0.150 & -0.024 & $-0.139 *$ & -0.144 \\
\hline & {$[0.093]$} & [0.129] & [0.091] & [0.091] \\
\hline Total effect (New dem.) & -1.539 & -2.198 & -4.246 & $-4.473^{* *}$ \\
\hline Total effect (Old dem.) & $-3.777^{*}$ & -5.822 & $-14.856 * *$ & $-3.969 * *$ \\
\hline F-test: difference & 0.55 & 0.38 & 2.33 & 0.03 \\
\hline \multicolumn{5}{|l|}{ Kleibergen-Paap rk Wald F } \\
\hline statistic & & & & 44.64 \\
\hline $\begin{array}{l}\text { Stock-Yogo 10\% critical } \\
\text { value }\end{array}$ & & & & 16.38 \\
\hline (Uncentered) $\mathrm{R}^{2}$ & 0.11 & 0.15 & 0.12 & 0.27 \\
\hline Observations & 327 & 127 & 327 & 327 \\
\hline
\end{tabular}

Note: Reform_ey and Reform_term denote reforms in the election year and in the rest of the incumbent leader term, respectively. Estimates based on equation (5). Standard deviations based on robust standard errors in parentheses. $* * *, * *, *$ denote significance at 1,5 and 10 percent, respectively. 
Table 16. The effect of reforms on electoral outcomes—Majoritarian vs. non-majoritarian systems

\begin{tabular}{|c|c|c|c|c|}
\hline & $\begin{array}{l}\text { (I) } \\
\text { OLS }\end{array}$ & $\begin{array}{c}\text { (II) } \\
\text { Ex. elections }\end{array}$ & $\begin{array}{l}\text { (III) } \\
\text { IMF }\end{array}$ & $\begin{array}{l}\text { (IV) } \\
\text { IV }\end{array}$ \\
\hline \multirow[t]{2}{*}{ Reform_ey (Maj) } & $-2.438^{*}$ & -2.913 & -10.178 & $-2.932 * *$ \\
\hline & [1.328] & {$[8.732]$} & [6.552] & [1.339] \\
\hline \multirow[t]{2}{*}{ Reform_ey (nonMaj) } & $-2.878 * *$ & $-3.921^{* * *}$ & $-4.334 *$ & $-7.587 * * *$ \\
\hline & [1.116] & [1.049] & [2.371] & [1.443] \\
\hline \multirow[t]{2}{*}{ Reform_term (Maj) } & 0.415 & 8.642 & -20.642 & -0.401 \\
\hline & [2.894] & [6.529] & {$[15.280]$} & [2.739] \\
\hline \multirow[t]{2}{*}{ Reform_term (nonMaj) } & -0.775 & -0.913 & -1.105 & -1.030 \\
\hline & [1.118] & [2.064] & [2.449] & [1.111] \\
\hline \multirow[t]{2}{*}{ Initial level regulation } & -6.574 & -1.748 & -1.809 & $-14.121 *$ \\
\hline & [6.199] & [14.801] & [6.064] & [7.257] \\
\hline \multirow[t]{2}{*}{ Growth_ey } & $0.505 * *$ & $0.459 *$ & $0.489 * *$ & $0.554 * *$ \\
\hline & {$[0.211]$} & {$[0.263]$} & {$[0.204]$} & [0.226] \\
\hline \multirow[t]{2}{*}{ Growth_term } & 0.428 & $1.206^{* *}$ & 0.448 & 0.342 \\
\hline & [0.325] & {$[0.568]$} & [0.315] & [0.337] \\
\hline \multirow{2}{*}{ Advanced economy } & $3.439 * *$ & $4.880 *$ & $2.759 * *$ & $3.677^{* * *}$ \\
\hline & [1.248] & [3.018] & {$[1.328]$} & [1.284] \\
\hline \multirow[t]{2}{*}{ New democracies } & 0.789 & 1.488 & 1.263 & 0.898 \\
\hline & [1.109] & {$[2.285]$} & [1.142] & [1.045] \\
\hline \multirow[t]{2}{*}{ Majoritarian system } & 1.906 & -2.089 & $2.690 * *$ & 1.265 \\
\hline & {$[1.660]$} & [3.501] & [1.200] & [1.545] \\
\hline \multirow[t]{2}{*}{ Lagged vote share } & -0.145 & 0.001 & -0.126 & -0.144 \\
\hline & [0.094] & [0.122] & {$[0.095]$} & {$[0.094]$} \\
\hline Total effect (Maj) & -2.022 & 5.729 & $-30.802 *$ & -7.987 \\
\hline Total effect (nonMaj) & $-3.653 * *$ & -4.834 & $-5.439 *$ & $-3.962 * * *$ \\
\hline F-test: difference & 0.17 & 1.64 & 2.34 & 2.30 \\
\hline Kleibergen-Paap rk Wald F statistic & & & & 32.90 \\
\hline Stock-Yogo $10 \%$ critical value & & & & 16.38 \\
\hline (Uncentered) $\mathrm{R}^{2}$ & 0.10 & 0.15 & 0.10 & 0.26 \\
\hline Observations & 327 & 127 & 327 & 327 \\
\hline
\end{tabular}

Note: Reform_ey and Reform_term denote reforms in the election year and in the rest of the incumbent leader term, respectively. Estimates based on equation (5). Standard deviations based on robust standard errors in parentheses. $* * *, * *, *$ denote significance at 1,5 and 10 percent, respectively. 
Table A1. Reforms and reversal in the electoral cycle

\begin{tabular}{lccccccccc}
\hline & All & IMF & Ex. El. & Adv. & Dev. & New dem. & Old dem. & Maj & nMAj \\
\cline { 2 - 9 } Reform_ey & 0.410 & 0.521 & 0.390 & 0.360 & 0.468 & 0.520 & 0.341 & 0.481 & 0.401 \\
Reform_ey (+) & 0.491 & 0.617 & 0.508 & 0.426 & 0.564 & 0.598 & 0.423 & 0.529 & 0.487 \\
Reversal_ey (-) & -0.072 & -0.087 & -0.106 & -0.059 & -0.086 & -0.068 & -0.075 & -0.043 & -0.079 \\
Reform_term & 0.628 & 0.860 & 0.632 & 0.605 & 0.654 & 0.685 & 0.594 & 0.526 & 0.650 \\
Reform_term (+) & 0.680 & 0.934 & 0.707 & 0.621 & 0.748 & 0.759 & 0.634 & 0.592 & 0.700 \\
Reversal_term (-) & -0.043 & -0.062 & -0.063 & -0.014 & -0.077 & -0.057 & -0.035 & -0.055 & -0.042
\end{tabular}

Note: Reform_ey and Reform_term denote reforms in the election year and in the rest of the incumbent leader term, respectively. Reform (+) and Reversal (-) denote liberalization and tightening reforms, respectively.

Table A2. Reforms and reversal in the electoral cycle-recessions vs expansions

\begin{tabular}{lcccccc}
\hline & \multicolumn{3}{c}{ Weak economic conditions } & \multicolumn{3}{c}{ Strong economic conditions } \\
\cline { 2 - 7 } & All & IMF & Ex. El. & All & IMF & Ex. El. \\
Reform_ey & 0.432 & 0.566 & 0.390 & 0.381 & 0.459 & 0.390 \\
Reform_ey (+) & 0.503 & 0.636 & 0.477 & 0.474 & 0.590 & 0.547 \\
Reversal_ey (-) & -0.065 & -0.069 & -0.081 & -0.081 & -0.108 & -0.136 \\
Reform_term & 0.687 & 1.024 & 0.686 & 0.555 & 0.703 & 0.568 \\
Reform_term (+) & 0.729 & 1.036 & 0.763 & 0.620 & 0.836 & 0.641 \\
Reversal_term (-) & -0.037 & -0.012 & -0.070 & -0.049 & -0.097 & -0.056 \\
\hline
\end{tabular}

Note: Reform_ey and Reform_term denote reforms in the election year and in the rest of the incumbent leader term, respectively. Reform (+) and Reversal (-) denote liberalization and tightening reforms, respectively. Weak and strong economic conditions are defined as in equation (2). 
Table A3. The effect of reforms on electoral outcomes-IMF Reforms vs. Reversals and recessions and expansions

\begin{tabular}{|c|c|}
\hline & IMF \\
\hline Reform_ey (+) (recessions) & $\begin{array}{c}-1.751 \\
{[12.331]}\end{array}$ \\
\hline Reversal_ey (-) (recessions) & $\begin{array}{c}-31.348 \\
{[26.763]}\end{array}$ \\
\hline Reform_term $(+)$ (recessions) & $\begin{array}{c}-5.002 \\
{[6.783]}\end{array}$ \\
\hline Reversal_term (-) (recessions) & $\begin{array}{c}-37.822^{* * *} \\
{[11.755]}\end{array}$ \\
\hline Reform_ey (+) (expansions) & $\begin{array}{l}-7.924 \\
{[4.907]}\end{array}$ \\
\hline Reversal_ey (-) (expansions) & $\begin{array}{c}47.293 \\
{[29.767]}\end{array}$ \\
\hline Reform_term $(+)$ (expansions) & $\begin{array}{c}1.839 \\
{[5.409]}\end{array}$ \\
\hline Reversal_term (-) (expansions) & $\begin{array}{c}326.53 * * * \\
{[71.920]}\end{array}$ \\
\hline Initial level regulation & $\begin{array}{c}-1.053 \\
{[5.738]}\end{array}$ \\
\hline Growth_ey & $\begin{array}{c}0.683 * * * \\
{[0.204]}\end{array}$ \\
\hline Growth_term & $\begin{array}{c}0.310 \\
{[0.324]}\end{array}$ \\
\hline Advanced economy & $\begin{array}{l}2.706 * * \\
{[1.352]}\end{array}$ \\
\hline New democracies & $\begin{array}{c}1.226 \\
{[1.151]}\end{array}$ \\
\hline Majoritarian system & $\begin{array}{c}2.142 * * \\
{[1.017]}\end{array}$ \\
\hline Lagged vote share & $\begin{array}{l}-0.155^{*} \\
{[0.088]}\end{array}$ \\
\hline Total effect recessions & -13.278 \\
\hline Total effect expansions & $273.15^{* * *}$ \\
\hline F-test: difference & $8.75^{* * *}$ \\
\hline $\begin{array}{l}\mathrm{R}^{2} \\
\text { Observations }\end{array}$ & $\begin{array}{l}0.12 \\
327 \\
\end{array}$ \\
\hline
\end{tabular}

Note: Reform_ey and Reform_term denote reforms in the election year and in the rest of the incumbent leader term, respectively. Reform (+) and Reversal (-) denote liberalization and tightening reforms, respectively. Estimates based on equation (5). Standard deviations based on robust standard errors in parentheses. ${ }^{* * *}, * *, *$ denote significance at 1,5 and 10 percent, respectively. 
Table A4. The Effect of Reforms on Re-election—single reforms

\begin{tabular}{|c|c|c|c|c|c|c|}
\hline & \multicolumn{3}{|c|}{ Financial } & \multicolumn{3}{|c|}{ Real } \\
\hline & (I) & (II) & (III) & (IV) & (V) & (VI) \\
\hline & $\begin{array}{l}\text { Domestic } \\
\text { finance }\end{array}$ & $\begin{array}{l}\text { Capital } \\
\text { account }\end{array}$ & $\begin{array}{l}\text { Fin.Current } \\
\text { account }\end{array}$ & Trade & $\begin{array}{l}\text { Product } \\
\text { market }\end{array}$ & $\begin{array}{l}\text { Labor } \\
\text { market }\end{array}$ \\
\hline Reform_ey & $\begin{array}{l}-2.545^{*} \\
(1.369)\end{array}$ & $\begin{array}{l}-6.574^{*} \\
(3.496)\end{array}$ & $\begin{array}{l}-5.210 * * \\
(2.105)\end{array}$ & $\begin{array}{l}0.314 \\
(0.635)\end{array}$ & $\begin{array}{l}-0.012 \\
(1.397)\end{array}$ & $\begin{array}{l}2.247 \\
(5.240)\end{array}$ \\
\hline Reform_term & $\begin{array}{l}-0.553 \\
(1.510)\end{array}$ & $\begin{array}{l}1.417 \\
(2.456)\end{array}$ & $\begin{array}{l}-0.480 \\
(2.044)\end{array}$ & $\begin{array}{l}-0.215 \\
(0.699)\end{array}$ & $\begin{array}{l}0.089 \\
(0.943)\end{array}$ & $\begin{array}{l}2.981 \\
(3.850)\end{array}$ \\
\hline $\begin{array}{l}\text { Initial level } \\
\text { regulation }\end{array}$ & $\begin{array}{l}-2.315 \\
(3.527)\end{array}$ & $\begin{array}{l}-1.247 \\
(4.970)\end{array}$ & $\begin{array}{l}-2.252 \\
(4.361)\end{array}$ & $\begin{array}{l}2.019 \\
(3.628)\end{array}$ & $\begin{array}{l}-0.397 \\
(3.020)\end{array}$ & $\begin{array}{l}-5.426 \\
(5.564)\end{array}$ \\
\hline Growth_ey & $\begin{array}{l}0.272 \\
(0.258)\end{array}$ & $\begin{array}{l}0.286 \\
(0.257)\end{array}$ & $\begin{array}{l}0.320 \\
(0.260)\end{array}$ & $\begin{array}{l}0.461 * * \\
(0.201)\end{array}$ & $\begin{array}{l}0.278 \\
(0.250)\end{array}$ & $\begin{array}{l}0.328 \\
(0.203)\end{array}$ \\
\hline Growth_term & $\begin{array}{l}0.727 * * \\
(0.309)\end{array}$ & $\begin{array}{l}0.676^{* *} \\
(0.317)\end{array}$ & $\begin{array}{l}0.679 * * \\
(0.315)\end{array}$ & $\begin{array}{l}0.472 \\
(0.326)\end{array}$ & $\begin{array}{l}0.725 * * \\
(0.322)\end{array}$ & $\begin{array}{l}0.679 * * \\
(0.298)\end{array}$ \\
\hline Advanced economy & $\begin{array}{l}3.275^{* * *} \\
(1.160)\end{array}$ & $\begin{array}{l}3.087 * * \\
(1.217)\end{array}$ & $\begin{array}{l}3.164^{* * * *} \\
(1.173)\end{array}$ & $\begin{array}{l}3.101^{* *} \\
(1.249)\end{array}$ & $\begin{array}{l}3.026 * * * \\
(1.023)\end{array}$ & $\begin{array}{l}2.839 * * \\
(1.067)\end{array}$ \\
\hline New democracies & $\begin{array}{l}0.714 \\
(1.152)\end{array}$ & $\begin{array}{l}0.648 \\
(1.148)\end{array}$ & $\begin{array}{l}0.792 \\
(1.090)\end{array}$ & $\begin{array}{l}0.761 \\
(1.155)\end{array}$ & $\begin{array}{l}0.708 \\
(1.133)\end{array}$ & $\begin{array}{l}0.476 \\
(1.132)\end{array}$ \\
\hline Majoritarian system & $\begin{array}{l}1.552 \\
(1.074)\end{array}$ & $\begin{array}{l}1.607 \\
(1.019)\end{array}$ & $\begin{array}{l}1.534 \\
(1.005)\end{array}$ & $\begin{array}{l}2.381 * * \\
(1.020)\end{array}$ & $\begin{array}{l}1.564 \\
(1.035)\end{array}$ & $\begin{array}{l}1.671 \\
(1.079)\end{array}$ \\
\hline Lagged vote share & $\begin{array}{l}-0.182^{* *} \\
(0.083)\end{array}$ & $\begin{array}{l}-0.185^{* *} \\
(0.082)\end{array}$ & $\begin{array}{l}-0.188^{* *} \\
(0.083)\end{array}$ & $\begin{array}{l}-0.151 \\
(0.093)\end{array}$ & $\begin{array}{l}-0.186^{* *} \\
(0.082)\end{array}$ & $\begin{array}{l}-0.185^{* *} \\
(0.079)\end{array}$ \\
\hline $\mathrm{R}^{2}$ & 0.10 & 0.10 & 0.10 & 0.09 & 0.09 & 0.10 \\
\hline Observations & 363 & 363 & 363 & 328 & 363 & 362 \\
\hline
\end{tabular}

Note: Reform_ey and Reform_term denote reforms in the election year and in the rest of the incumbent leader term, respectively. Estimates based on equation (1). Standard deviations based on robust standard errors in parentheses. $* * *, * *, *$ denote significance at 1,5 and 10 percent, respectively. 
Table A5. The effect of reforms on electoral outcomes—Financial vs. real and Reforms vs. Reversals

\begin{tabular}{|c|c|c|}
\hline & $\begin{array}{c}\text { (I) } \\
\text { Financial }\end{array}$ & $\begin{array}{l}\text { (II) } \\
\text { Real }\end{array}$ \\
\hline Reform_ey (+) & $\begin{array}{c}-6.889 * * \\
{[2.823]}\end{array}$ & $\begin{array}{c}1.313 \\
{[2.229]}\end{array}$ \\
\hline Reversal_ey (-) & $\begin{array}{c}11.105 \\
{[7.363]}\end{array}$ & $\begin{array}{c}-5.918 \\
{[15.389]}\end{array}$ \\
\hline Reform_term (+) & $\begin{array}{c}0.318 \\
{[2.838]}\end{array}$ & $\begin{array}{c}0.611 \\
{[1.609]}\end{array}$ \\
\hline Reversal_term (-) & $\begin{array}{c}0.910 \\
{[5.889]}\end{array}$ & $\begin{array}{l}12.443 \\
{[7.639]}\end{array}$ \\
\hline Initial level regulation & $\begin{array}{c}-2.532 \\
{[5.030]}\end{array}$ & $\begin{array}{c}1.420 \\
{[6.302]}\end{array}$ \\
\hline Growth_ey & $\begin{array}{c}0.289 \\
{[0.265]}\end{array}$ & $\begin{array}{c}0.463^{* *} \\
{[0.210]}\end{array}$ \\
\hline Growth_term & $\begin{array}{c}0.683^{* *} \\
{[0.331]}\end{array}$ & $\begin{array}{c}0.490 \\
{[0.328]}\end{array}$ \\
\hline Advanced economy & $\begin{array}{l}3.352 * * \\
{[1.293]}\end{array}$ & $\begin{array}{c}3.338 * * * \\
{[1.183]}\end{array}$ \\
\hline New democracies & $\begin{array}{c}0.726 \\
{[1.109]}\end{array}$ & $\begin{array}{c}0.812 \\
{[1.175]}\end{array}$ \\
\hline Majoritarian system & $\begin{array}{c}1.541 \\
{[1.046]}\end{array}$ & $\begin{array}{c}2.384 * * \\
{[1.020]}\end{array}$ \\
\hline Lagged vote share & $\begin{array}{c}-0.182 * * \\
{[0.084]}\end{array}$ & $\begin{array}{c}-0.162 * \\
{[0.087]}\end{array}$ \\
\hline F-test reform vs. reversal coef. & 0.36 & 0.21 \\
\hline $\mathrm{R}^{2}$ & 0.11 & 0.09 \\
\hline Observations & 363 & 327 \\
\hline
\end{tabular}

Note: Reform_ey and Reform_term denote reforms in the election year and in the rest of the incumbent leader term, respectively. Reform (+) and Reversal (-) denote liberalization and tightening reforms, respectively. Estimates based on equation (5). Standard deviations based on robust standard errors in parentheses. ${ }^{* * *},{ }^{* *}, *$ denote significance at 1,5 and 10 percent, respectively. 
Table A6. The effect of reforms on electoral outcomes—recessions vs. expansions, financial vs. real

\begin{tabular}{|c|c|c|c|c|c|c|}
\hline & $\begin{array}{c}\text { (I) } \\
\text { Dom. Fin }\end{array}$ & $\begin{array}{c}\text { (II) } \\
\text { Capital }\end{array}$ & $\begin{array}{c}\text { (I) } \\
\text { Fin. Curr. }\end{array}$ & $\begin{array}{l}\text { (II) } \\
\text { Trade }\end{array}$ & $\begin{array}{l}\text { (I) } \\
\text { PMR }\end{array}$ & $\begin{array}{c}\text { (II) } \\
\text { LMR }\end{array}$ \\
\hline \multirow[t]{2}{*}{ Reform_ey (recessions) } & $-6.183^{* * *}$ & -5.507 & $-10.153^{* * *}$ & -2.597 & 2.678 & 2.707 \\
\hline & {$[2.300]$} & [7.392] & [2.354] & [2.637] & [5.449] & [12.409] \\
\hline \multirow[t]{2}{*}{ Reform_ey (expansions) } & 1.138 & -8.038 & 0.471 & 2.653 & -1.541 & 1.410 \\
\hline & [2.552] & [7.198] & [3.509] & [1.865] & [3.333] & [28.763] \\
\hline \multirow{2}{*}{ Reform_term (recessions) } & -4.000 & 1.169 & 2.357 & -2.144 & -5.010 & 9.286 \\
\hline & [3.367] & {$[2.876]$} & [2.011] & [1.858] & [3.195] & {$[8.292]$} \\
\hline \multirow{2}{*}{ Reform_term (expansions) } & 2.402 & 1.651 & -3.004 & 1.435 & $3.475^{*}$ & 0.714 \\
\hline & {$[2.721]$} & [5.796] & [4.194] & {$[3.804]$} & [1.854] & {$[6.925]$} \\
\hline \multirow[t]{2}{*}{ Initial level regulation } & -2.414 & -1.363 & -1.171 & 1.562 & 0.048 & -4.989 \\
\hline & [2.721] & [5.014] & [4.194] & {$[3.805]$} & [3.040] & [5.518] \\
\hline \multirow[t]{2}{*}{ Growth_ey } & $0.208^{* *}$ & 0.288 & 0.302 & $0.465 * *$ & 0.338 & 0.320 \\
\hline & {$[0.260]$} & [0.258] & {$[0.263]$} & {$[0.206]$} & {$[0.276]$} & {$[0.208]$} \\
\hline \multirow[t]{2}{*}{ Growth_term } & $0.633^{* *}$ & $0.674^{* *}$ & $0.700^{* *}$ & 0.444 & 0.535 & $0.673^{* *}$ \\
\hline & [0.315] & {$[0.321]$} & [0.314] & {$[0.343]$} & {$[0.360]$} & {$[0.306]$} \\
\hline \multirow[t]{2}{*}{ Advanced economy } & $3.111 * * *$ & $3.105^{* *}$ & $3.142^{* *}$ & $3.172^{* *}$ & $2.715^{* * *}$ & $2.873 * * *$ \\
\hline & [1.159] & [1.225] & [1.215] & [1.252] & [1.024] & {$[1.055]$} \\
\hline \multirow[t]{2}{*}{ New democracies } & 0.523 & 0.628 & 0.994 & 0.769 & 0.762 & 0.562 \\
\hline & [1.140] & [1.145] & [1.094] & [1.166] & {$[1.083]$} & {$[1.086]$} \\
\hline \multirow[t]{2}{*}{ Majoritarian system } & 1.561 & $1.631^{* *}$ & 1.404 & $2.238 * *$ & 1.487 & 1.647 \\
\hline & [1.068] & [1.034] & [1.036] & {$[1.020]$} & [1.060] & {$[1.074]$} \\
\hline \multirow[t]{2}{*}{ Lagged vote share } & -0.179 & $-0.186^{* *}$ & $-0.185^{* *}$ & -0.153 & $-0.185^{* *}$ & $-0.183^{* *}$ \\
\hline & {$[0.083]$} & {$[0.084]$} & {$[0.084]$} & {$[0.093]$} & {$[0.082]$} & {$[0.077]$} \\
\hline Total effect recessions & $-10.183^{* * *}$ & -4.338 & $-7.796 * * *$ & $-4.741^{*}$ & -2.332 & 11.994 \\
\hline Total effect expansions & 3.541 & -6.387 & -2.533 & $4.088^{*}$ & 1.933 & 2.124 \\
\hline F-test difference & $4.73^{* *}$ & 0.02 & 0.55 & $2.63^{*}$ & 0.33 & 0.57 \\
\hline $\mathrm{R}^{2}$ & 0.11 & 0.09 & 0.11 & 0.09 & 0.10 & 0.05 \\
\hline Observations & 363 & 363 & 363 & 327 & 363 & 363 \\
\hline
\end{tabular}

Note: Reform_ey and Reform_term denote reforms in the election year and in the rest of the incumbent leader term, respectively. Estimates based on equation (4). Standard deviations based on robust standard errors in parentheses. ***,**,* denote significance at 1,5 and 10 percent, respectively. 
Table A7. The effect of reforms on electoral outcomes_IMF Advanced vs. developing

\begin{tabular}{|c|c|}
\hline & IMF \\
\hline \multirow[t]{2}{*}{ Reform_ey(Adv.) } & $-9.126 * *$ \\
\hline & [3.655] \\
\hline \multirow[t]{2}{*}{ Reform_ey(Dev.) } & $-4.927 * *$ \\
\hline & {$[2.085]$} \\
\hline \multirow[t]{2}{*}{ Reform_term(Adv.) } & $-29.085 * * *$ \\
\hline & {$[5.376]$} \\
\hline \multirow[t]{2}{*}{ Reform_term(Dev.) } & -0.006 \\
\hline & [2.187] \\
\hline \multirow[t]{2}{*}{ Initial level regulation } & -0.085 \\
\hline & {$[5.880]$} \\
\hline \multirow[t]{2}{*}{ Growth_ey } & $0.534^{* *}$ \\
\hline & {$[0.202]$} \\
\hline \multirow[t]{2}{*}{ Growth_term } & 0.485 \\
\hline & {$[0.304]$} \\
\hline \multirow[t]{2}{*}{ Advanced economy } & $3.262 * *$ \\
\hline & [1.313] \\
\hline \multirow[t]{2}{*}{ New democracies } & 0.958 \\
\hline & [1.127] \\
\hline \multirow[t]{2}{*}{ Majoritarian system } & $2.007 *$ \\
\hline & [1.009] \\
\hline \multirow[t]{2}{*}{ Lagged vote share } & -0.11 \\
\hline & {$[0.092]$} \\
\hline Total effect (Adv.) & $-38.210 * * *$ \\
\hline Total effect (Dev.) & -4.933 \\
\hline F-test: difference & $19.14 * * *$ \\
\hline $\mathrm{R}^{2}$ & 0.12 \\
\hline Observations & 327 \\
\hline
\end{tabular}

Note: Reform_ey and Reform_term denote reforms in the election year and in the rest of the incumbent leader term, respectively. Estimates based on equation (5). Standard deviations based on robust standard errors in parentheses. $* * *, * *, *$ denote significance at 1,5 and 10 percent, respectively. 
Table A8. The effect of reforms on electoral outcomes—extensions

\begin{tabular}{|c|c|c|c|c|}
\hline & $\begin{array}{c}\text { (I) } \\
\text { Gov. alone } \\
\text { vs. coalition }\end{array}$ & $\begin{array}{c}\text { (II) } \\
\text { Adv. Vs. } \\
\text { Dev }\end{array}$ & $\begin{array}{c}\text { (III) } \\
\text { New vs. } \\
\text { OLD dem. }\end{array}$ & $\begin{array}{c}\text { (IV) } \\
\text { Maj. vs. } \\
\text { nonMaj. }\end{array}$ \\
\hline Reform_ey*D (recessions) & $\begin{array}{c}-5.533 * * * \\
{[1.119]}\end{array}$ & $\begin{array}{c}1.263 \\
{[5.907]}\end{array}$ & $\begin{array}{c}-5.107 * * * \\
{[1.238]}\end{array}$ & $\begin{array}{c}-13.867 * * \\
{[6.287]}\end{array}$ \\
\hline Reform_ey*D (expansions) & $\begin{array}{c}-0.678 \\
{[1.862]}\end{array}$ & $\begin{array}{c}-2.800 \\
{[3.503]}\end{array}$ & $\begin{array}{c}-1.296 \\
{[4.286]}\end{array}$ & $\begin{array}{c}0.441 \\
{[1.783]}\end{array}$ \\
\hline Reform_term*D (recessions) & $\begin{array}{c}-1.735 \\
{[2.106]}\end{array}$ & $\begin{array}{c}-2.780 \\
{[2.626]}\end{array}$ & $\begin{array}{c}1.135 \\
{[2.180]}\end{array}$ & $\begin{array}{l}-3.192 \\
{[4.814]}\end{array}$ \\
\hline Reform_term*D (expansions) & $\begin{array}{c}1.022 \\
{[3.269]}\end{array}$ & $\begin{array}{c}0.731 \\
{[2.509]}\end{array}$ & $\begin{array}{c}3.682 \\
{[3.420]}\end{array}$ & $\begin{array}{c}3.795 \\
{[5.607]}\end{array}$ \\
\hline Reform_ey*(1-D) (recessions) & $\begin{array}{c}13.221 \\
{[10.485]}\end{array}$ & $\begin{array}{c}-5.150 * * * \\
{[1.295]}\end{array}$ & $\begin{array}{c}2.682 \\
{[5.703]}\end{array}$ & $\begin{array}{c}-4.023^{* *} \\
{[1.848]}\end{array}$ \\
\hline Reform_ey*(1-D) (expansions) & $\begin{array}{c}-12.472 \\
{[8.363]}\end{array}$ & $\begin{array}{c}-2.352 \\
{[3.924]}\end{array}$ & $\begin{array}{c}-3.975 \\
{[3.302]}\end{array}$ & $\begin{array}{c}-1.285 \\
{[3.199]}\end{array}$ \\
\hline Reform_term*(1-D) (recessions) & $\begin{array}{c}-0.926 \\
{[4.596]}\end{array}$ & $\begin{array}{c}-1.621 \\
{[2.973]}\end{array}$ & $\begin{array}{l}-4.644^{*} \\
{[2.339]}\end{array}$ & $\begin{array}{c}-1.339 \\
{[2.003]}\end{array}$ \\
\hline Reform_term*(1-D) (expansions) & $\begin{array}{c}-4.006 \\
{[4.086]}\end{array}$ & $\begin{array}{c}0.069 \\
{[3.846]}\end{array}$ & $\begin{array}{c}-0.796 \\
{[2.832]}\end{array}$ & $\begin{array}{c}-0.398 \\
{[2.407]}\end{array}$ \\
\hline Initial level regulation & $\begin{array}{c}-6.700 \\
{[6.015]}\end{array}$ & $\begin{array}{c}-7.215 \\
{[6.150]}\end{array}$ & $\begin{array}{c}-8.763 \\
{[6.345]}\end{array}$ & $\begin{array}{c}-7.073 \\
{[6.208]}\end{array}$ \\
\hline Growth_ey & $\begin{array}{c}0.546 * * \\
{[0.212]}\end{array}$ & $\begin{array}{c}0.533 * * \\
{[0.226]}\end{array}$ & $\begin{array}{c}0.572 * * \\
{[0.226]}\end{array}$ & $\begin{array}{c}0.457 * * \\
{[0.215]}\end{array}$ \\
\hline Growth_term & $\begin{array}{c}0.417 \\
{[0.352]}\end{array}$ & $\begin{array}{c}0.332 \\
{[0.0 .372]}\end{array}$ & $\begin{array}{c}0.253 \\
{[0.354]}\end{array}$ & $\begin{array}{c}0.398 \\
{[0.354]}\end{array}$ \\
\hline Advanced economy & $\begin{array}{c}3.691^{* * *} \\
{[1.246]}\end{array}$ & $\begin{array}{c}2.991 * * \\
{[1.475]}\end{array}$ & $\begin{array}{c}3.638 * * * \\
{[1.198]}\end{array}$ & $\begin{array}{c}3.261^{* * *} \\
{[1.269]}\end{array}$ \\
\hline New democracies & $\begin{array}{c}0.996 \\
{[1.159]}\end{array}$ & $\begin{array}{c}0.734 \\
{[1.154]}\end{array}$ & $\begin{array}{c}-0.500 \\
{[1.583]}\end{array}$ & $\begin{array}{c}0.655 \\
{[1.138]}\end{array}$ \\
\hline Majoritarian system & $\begin{array}{c}2.012^{* *} \\
{[0.989]}\end{array}$ & $\begin{array}{c}2.372^{* *} \\
{[0.964]}\end{array}$ & $\begin{array}{c}2.328 * * * \\
{[0.879]}\end{array}$ & $\begin{array}{c}2.184 \\
{[1.720]}\end{array}$ \\
\hline Lagged vote share & $\begin{array}{c}-0.132 \\
{[0.092]}\end{array}$ & $\begin{array}{c}-0.140 \\
{[0.094]}\end{array}$ & $\begin{array}{c}-0.150 \\
{[0.093]}\end{array}$ & $\begin{array}{c}-0.142 \\
{[0.096]}\end{array}$ \\
\hline Total D & $-6.924 * *$ & -3.586 & -1.586 & -12.823 \\
\hline Total (1-D) & -4.183 & $-9.054 *$ & -6.732 & -7.046 \\
\hline F-test difference & 0.51 & 1.03 & 0.68 & 0.40 \\
\hline $\mathrm{R}^{2}$ & 0.12 & 0.11 & 0.12 & 0.11 \\
\hline Observations & 327 & 327 & 327 & 327 \\
\hline
\end{tabular}

Note: Reform_ey and Reform_term denote reforms in the election year and in the rest of the incumbent leader term, respectively. Estimates based on equation (5), differentiating between recessions and expansions. Standard deviations based on robust standard errors in parentheses. D (1-D) respectively denotes governing alone (coalition) column I; advanced (developing) economies-column II; new (old) democracies—column III; majoritarian (non-majoritarian) systems—column IV. ***,**,* denote significance at 1,5 and 10 percent, respectively. 